\title{
Merging Architectural Structures with Forest Walkways: A Comprehensive Review of Treetop Walkways and the Fu Forest Trail of China
}

\author{
Yan Ke ${ }^{1}$, Yuebin Lin ${ }^{2}$, Jian Liu ${ }^{3}$, Qingxi Chen ${ }^{1}$, Baoying Shen ${ }^{1}$, Xiayu Guan ${ }^{1}$ and Biying Lin ${ }^{1}$ ** \\ 1 College of Horticulture, Fujian Agriculture and Forestry University, Fuzhou 350002, China; \\ fjfzkeyan@126.com (Y.K.); cqx0246@163.com (Q.C.); shenby889@fafu.edu.cn (B.S.); gxy302@126.com (X.G.) \\ 2 College of Design and Innovation, Fujian Jiangxia University, Fuzhou 350108, China; fjlinyuebin@126.com \\ 3 College of Forestry, Fujian Agriculture and Forestry University, Fuzhou 350002, China; fjliujian@126.com \\ * Correspondence: 000q020019@fafu.edu.cn; Tel.: +1-390-501-5517
}

Citation: Ke, Y.; Lin, Y.; Liu, J.; Chen, Q.; Shen, B.; Guan, X.; Lin, B. Merging Architectural Structures with Forest Walkways: A Comprehensive Review of Treetop Walkways and the Fu Forest Trail of China. Forests 2021, 12, 1343. https://doi.org/10.3390/f12101343

Academic Editor: Chi Yung Jim

Received: 2 September 2021

Accepted: 27 September 2021

Published: 30 September 2021

Publisher's Note: MDPI stays neutral with regard to jurisdictional claims in published maps and institutional affiliations.

Copyright: (c) 2021 by the authors. Licensee MDPI, Basel, Switzerland. This article is an open access article distributed under the terms and conditions of the Creative Commons Attribution (CC BY) license (https:/ / creativecommons.org/licenses/by/ $4.0 /)$.

\begin{abstract}
Treetop walkways are unique trail constructions. Their support structure suspends a walkway platform several meters from the ground, shuttling among the canopies of trees in the forest. Many countries have built canopy trails for forest recreation, tourism, and other uses. In certain cities, the treetop walkway is no longer a single building unit or forest trail in the narrow sense, and is planned as a multi-functional urban public landscape. This study reviews the development of treetop and elevated forest trails, introduces several representative cases, and provides a comprehensive reference point that fills previous research gaps. We also analyze the Fu Forest Trail, the most representative treetop walkway in China through, inter alia, its modular system, elevated structural, and design appearance. We explore the background and application of treetop trails that connect residents and the environment as a multifunctional urban public landscape in China, and related future research directions. We conclude that treetop walkways have many distinct advantages, and are becoming trendy in forest trail development; there is excellent potential to transform them creatively and innovatively into high-quality forest infrastructure or urban public landscape for public benefit.
\end{abstract}

Keywords: treetop walkway; forest recreation; modular system; elevated structural design; Fu Forest Trail; human habitat environment; urban public landscape

\section{Introduction}

The rapid development of recreation has changed the functional value and management directions of land types. The forest is a typical example of this: the value of modern forests is no longer reflected in economic benefits from the direct use of wood [1]. People's forest needs and demands are gradually moving toward healthcare and fitness, tourism and recreational values, and landscape appreciation experiences [2-6]. In the United States, Canada, Australia, Japan, and many European countries, millions of people frequently visit forests for recreational activities every year, and this number is rising $[7,8]$, making forest recreation research particularly significant [1].

Effective forest trail planning and aesthetic designing can improve the attraction of forest areas and promote their recreational value, promoting economic benefits $[1,2,8,9]$. The trail is an important infrastructure with many functions for the forest area. First, it is a landscape corridor that plays a role in organizing the landscape space. Well-designed forest trails enable visitors to enjoy the forest landscape more thoroughly than poorly designed structures do [1]. Second, people rely on forest trails for hiking, cycling, forest bathing, family communication, and social activities. Many forest recreational activities can relieve stress and promote relaxation among visitors completing forest trails [10-15]. Trail designers must consider the needs of visitors by improving their structural characteristics to meet the relevant attributes $[1,2,9]$. 
In the 1980s, a new form of forest trail appeared in dense forests: the treetop walkway comprising a support structure for a walkway platform in the air that allows pedestrians to travel freely between the canopies. With various improvements in the past three decades, treetop walkways are now quite visitor-friendly, with comprehensive functions that meet the multifarious needs of the public [16]. First, like a ground-based trail, a treetop walkway ensures that the public integrates with nature in a relaxed state. Its users can exercise in a reasonably safe way while enjoying the rehabilitative effect of the forest, facilitating sightseeing, sports, and ecological recuperation in daily life. It is an integration of the forest trail and building structure, and has advantages that ground-foundation forest trails lack: more possibilities for design, rich structural changes and unique visual effects, better adaptability to complex terrains, and impressive recreational experience. Recent research has demonstrated that elevated trails may have a positive effect on tourists' restorative experiences and psychology with respect to place attachment and well-being because of their deep recreational involvement and significant user preferences $[17,18]$.

So far, several canopy trails have been built in Australia, New Zealand, Singapore, Germany, China, and other countries [19]. Some of these are located in national nature reserves and virgin forests, serving as science popularization and sightseeing corridors. Some, designed to be futuristic and aesthetic buildings, constitute core holiday attractions for tourists, promoting commercial forest recreational tourism. Beyond these, in urban forests, treetop walkways no longer comprise a single building unit or forest trail in the narrow sense, but make up an elevated slow-walking system that spans long distances, rich supporting facilities, and urban public landscapes connecting residents with environment, while improving the livability of the city. Indeed, in certain mountainous cities of China, they have become a principle means of promoting forest recreational development and improving the living environment [20-22], or the main connecting structure of mountainous greenways. However, research on treetop trails is still scarce, and there is as yet no comprehensive review on this distinctive trail-building. This study aims to fill this gap in research and clarify important aspects of elevated forest trails for interested scholars.

In this study, the origin and development of treetop walks are introduced, and global information on 40 treetop walkways is summarized (Table A1) and their particularities or advantages over ground-based forest trails are explored, focusing on projects related to livelihood and the human habitat environment, particularly the Fu Forest Trail, the most representative treetop walkway in China. This study explores the Fu Forest trail in detail based on the hypothesis that its design could constitute a reference point that many mountainous and hilly cities can imitate (e.g., the modular system, elevated structural design, appearance, planned objectives, and the combination of functional design and engineering efficiency) and thus contribute to the better livelihoods of the locals.

\section{Materials and Methods}

The survey began in 2017. Materials collection and other related research about treetop walkway lasted for 4 years. But suspension bridge walkway without architectural supporting structure, and some bridge winding through rocks and cliffs were excluded from the study.

The materials for this study were predominantly obtained from:

1. An original survey of the origin, development, and latest research trends on many cases of treetop walkways from dissertations and journals.

2. We visited and explored the official websites of scenic spots where treetop walkways are located and the official websites of their management departments and design units to collect the specific information and details of each case (e.g., geographical location, current situation and management condition, flow of tourists and its evaluation).

3. With the assistance of the urban planning department, we obtained valuable images and text materials, including the relevant planning documents, design guide- 
lines, engineering construction materials, and text related to the background of urban development.

4. Site visit and on-site photos.

We employed a narrative approach to elaborate on the findings of our study.

\section{Results}

3.1. Origin and Development

\subsubsection{Early Designs}

Treetop walkways were originally created to meet the need for scientific research on canopy species in 1981 by the entomologist Terry Erwin. In his research on beetles in the Panamanian rainforest canopy [23], he discovered numerous new species and extrapolated that there were many potential species in the crown of plants not yet discovered [24,25]. To observe and obtain specimens of arboreal animals, insects, epiphytes, and lianas and investigate the morphology of trees and leaves in the tree canopy, researchers took the following measures: using ropes, ladders, hydraulic cranes, and pulleys fixed by iron rods, as well as domesticated macaque monkeys to help in sample collection [23,26]. To travel freely within the canopy area and minimize the damage to the canopy and surface ecosystems, researchers finally designed an arboreal high-wire network that can be suspended, the first prototype of the treetop walkway [23,27]. Scientific discoveries of the tree canopy stimulated efforts to take the public up into the forest heights. With the fading of the canopy research boom, the design concept of the treetop walkway gradually shifted toward affording the people popular science, fitness, forest recreation, and sightseeing experiences. Many such routes were opened to the public in the early 1990s and became widely popular [28]. In the 21st century, increasing numbers of treetop walkways have been "transplanted" in the urban area, to become unique urban landscapes and livelihood projects.

In 1987, O'Reilly's Treetop Walk, considered the first treetop walkway in the world, was opened to the public at Lamington National Park in Australia [29]. Since then, such trails have become popular attractions in forest areas, nature reserves, and national and botanical parks far away from city centers [23]. The structures of early designs were generally simple, some being similar to suspension bridges. The main materials used were wood, steel bars, and relatively rough iron chains. They afforded visitors a rare experience of biodiversity and forest charm from a unique perspective and quickly became the most attractive scenic spot within each area after their completion. For example, the Valley of the Giants Tree Top Walkway at Walpole-Nornalup National Park in Australia passes through a 400-year-old forest of red tingle trees. Not only does it provide a convenient path for researchers to get close to the canopy of this rare tree species, which is endemic to the Australian mainland, but it has also become the trendiest attraction and a popular science corridor for this forest area after being opened to tourists due to its suspended height of $40 \mathrm{~m}$. At that time, the Valley of the Giants and the elevated trail received enormous exposure in the media and were adopted as a tourist site for Western Australia [30]. Before its completion, the scenic spot received about 120,000 tourists annually; after the completion of the trail in 1996, it saw a significant increase in visitors (especially from 1999 to 2003, which remained relatively constant with a mean of 200,134 visitors annually) [28,30-32] (Figure 1). The primary purpose for tourist visits was the treetop walk (Figure 2). The Valley of the Giants earned over AUD 2.5 million in revenues by 1999; by July 2003, over 1.3 million people (many of them repeat visitors) had visited the site [33-38]. The same situation occurred in the Royal Forest of Salcey, Northamptonshire, UK, where visitor numbered 500,000 over the first 2 years after the opening of a treetop walkway $300 \mathrm{~m}$ long and $20 \mathrm{~m}$ high. The forest department had to restrict the number of visitors during the holidays [39]. 


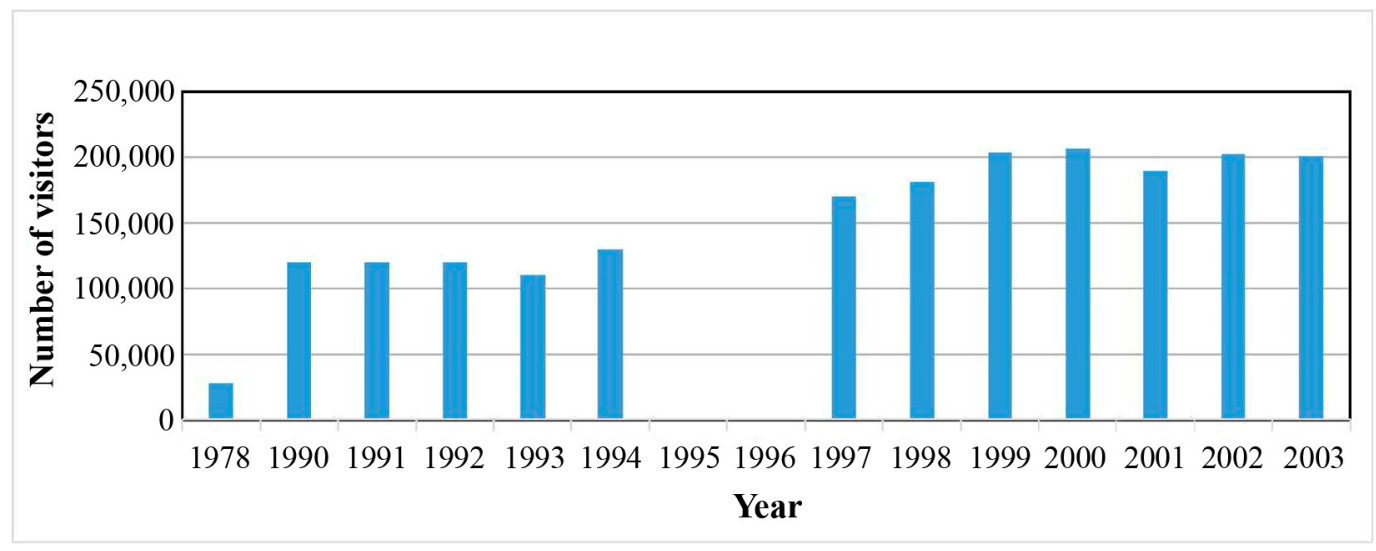

Figure 1. Number of visitors every year to Walpole-Nornalup National Park. Note: The data were not collected in 1995 and 1996 (Source: author remade according to reference [30]).

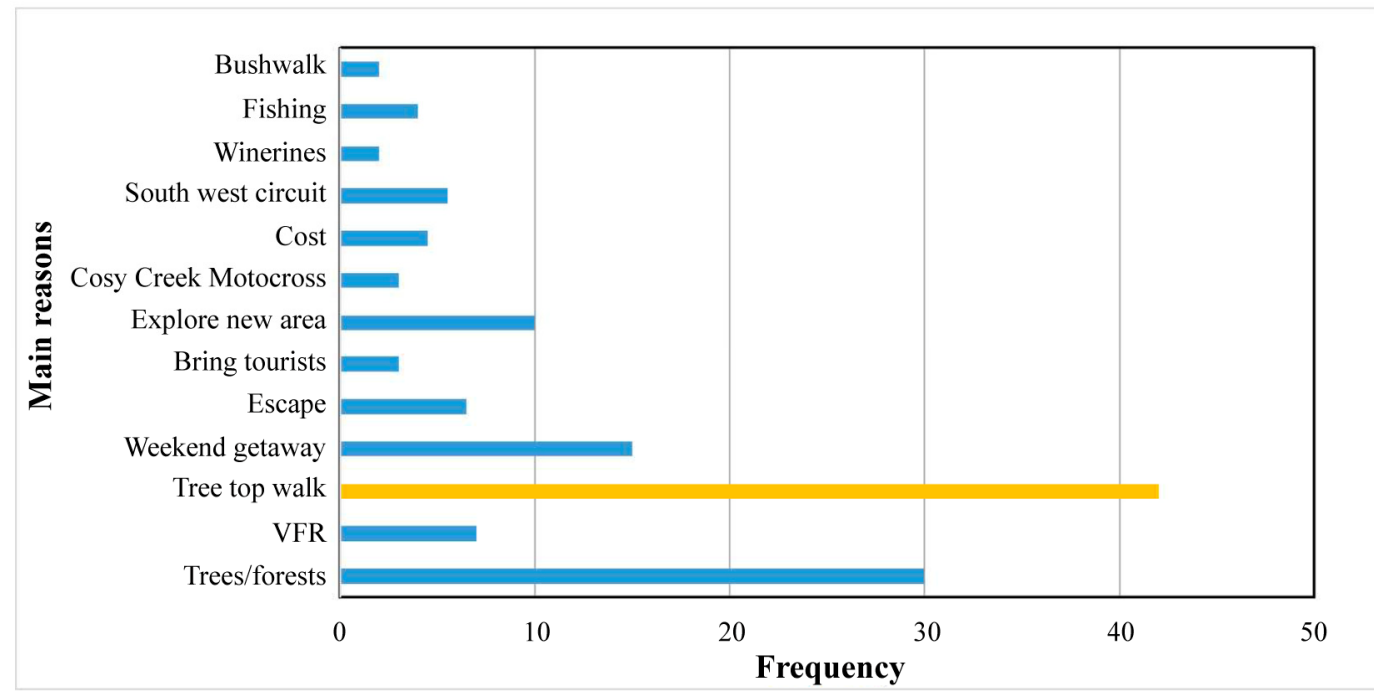

Figure 2. Reasons for visiting the Valley of the Giants (Source: author remade according to reference [38]).

\subsubsection{Improvement and Development}

At the turn of the 21st century, to meet the higher demand of urban residents for sightseeing and recreation, the structural design of treetop walkways focused on safety, stability, and beauty [40]. The treetop walkway in Kew Gardens, designed by Marks Barfield Architects, is a typical example from this period.

For the trail's $200 \mathrm{~m}$ length and $18 \mathrm{~m}$ suspended height, a truss structure was adopted. Circular rest platforms were placed at all the joints of the bridge deck truss and lower supporting structures. The design team organized the truss structure following a Fibonacci sequence. The density of the truss web members increases where the load increases, displaying the visual effect of the web members as they gradually became denser from the center of the truss to both ends. This forms the facade characteristic of the entire elevated walkway. The web members of the truss also act as balustrades. Designers believed that suitable design work can deepen the harmonious relationship between people, architecture, and the natural environment. In addition to the steel, which is colored dark brown (similar to wood), all the supporting structures embedded in the bottom concrete pile also imitate tree branches and present a Y-shape to hide the unnatural appearance of artificial buildings and make the steel footpath more vivid, thus integrating the trail and the surrounding environment in an elegant fashion [41-43] (Figure 3). 


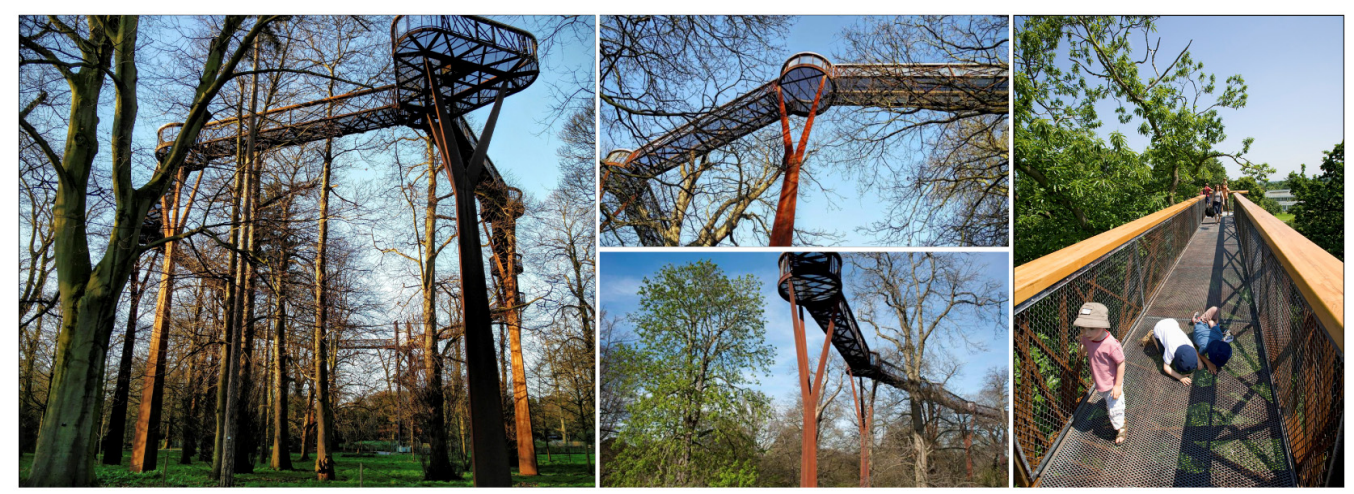

Figure 3. Photos of the Kew Gardens taken from different angles (Source: https:/ /www.kew.org/ kew-gardens/whats-in-the-gardens/treetop-walkway, accessed on 25 July 2021; and reference [41]).

In the past decade, with the growth of sightseeing, the unique experience of treetop walking, and the science popularization of biodiversity, treetop trails have developed into popular forest recreation and entertainment projects in some countries. Combined with ticketing management, tourism exploration, camping, souvenir sales, catering, and other activities, it is thriving as a branch of the highly commercial forest tourism industry, so much so that specialized companies or organizations now undertake their design, construction, and management.

For example, Canopy 01, an ecotourism company located in Tasmania, Australia, has a complete set of designs, construction, operations, and investment promotion plans for canopy trail projects [44]. They have developed many projects in Australia and New Zealand (e.g., the Otway Fly Treetop Walk, Tahune Airwalk, and Illawarra Fly). They are participating in more development of forest tourism and leisure projects related to treetop walkways in Ireland, Cambodia, Canada, the United States, among others. The Westcoast Treetop Walk in the rainforest of Christchurch is a highly commercialized canopy trail project that has become a landmark tourist attraction in New Zealand, also a famous project of Canopy 01. The elevated platform is suspended $20 \mathrm{~m}$ from the ground and is made of polished reinforcing bars that join a 40-m-high viewing tower, Hokitika, overlooking the Southern Alps, Lake Mahinapua, and the entire rainforest reserve [45]. Many barrier-free ramps were designed to facilitate the passage of wheelchairs and baby carriages to allow people of all ages. Commercial support facilities include a cafe, a small restaurant, a pub, a tourist center that can accommodate 120 people, a souvenir retail store, and parking lots.

In Europe, the design of treetop walkways and the operation modes of commercial tourism are now standardized. In particular, Germany has a well-rounded design concept and rich experience for the construction of overhead forest walkways and many successful achievements in their commercial operation and tourism promotion. Designers and operators are clear regarding tourists' experiences and preferences to create exciting and novel theme projects, leading to fun-filled tourism that has yielded considerable commercial benefits. For the past 10 years, die Erlebnis Akademie Ag (eak) of Germany has successfully built and operated more than 10 commercial-forest tourism projects with the theme of overhead forest trails in the holiday regions of the Bavarian forests and the national forest parks of the Czech Republic, Slovenia, Austria, France, and other European countries (Figure A1) [40,46-55]. These trails all have similar design principles: The long-distance treetop walks are more than $1000 \mathrm{~m}$ long, with a suspended height of about $20 \mathrm{~m}$, meandering through beech, firs, spruce trees, and other common mixed species of continental climates. The highlights are giant lookout towers (the average height is above $40 \mathrm{~m}$ ) at the end of the walkways that provide visitors with an impressive bird's-eye view as a sightseeing experience (a dry slide often runs through the middle of the observation tower that the tourists may use to shorten the way back down while enjoying a healthy dose of adrenaline). The nature experience facilities are easily accessible to all, so that visits 
are effortless for the target groups of families with toddlers and prams, as well as senior groups. Even wheelchair users and people who rely on rollators can easily use the paths.

\subsubsection{New Roles in Livelihood and Urban Environments}

In 2008, Singapore National Parks Board took the lead in introducing the design concept of the treetop walkway into the dense forests and parks of Southern Ridges to improve the national greenway (park connector) network. The Southern Ridges Greenway, $9 \mathrm{~km}$ in length, consists of four green patches (Mount Faber Park, Telok Blangah Hill Park, Hortpark, Kent Ridge Park) and seven mountainous trails (Marang Trail, Faber Trail, Henderson Waves Footbridge, Hilltop Walk, Forest Walk, Alexandra Arch, and Canopy Walk). Of these, the Hilltop Walk and Forest Walk of the Telok Blangah Hill Park section are treetop walks with complete steel structures. The Canopy Walk, which passes along Kent Ridge Park, is at a $16 \mathrm{~m}$ height with woody materials [19,56]. The 284 meters long Henderson Waves Footbridge has an overhead height of $36 \mathrm{~m}$, providing visitors with an excellent bird's eye view. The Alexandra Arch is a pedestrian overpass with a modernist design style and a main entrance for citizens to start the footpath line and avoid the traffic flow (Figure A2) [56-58].

The Southern Ridges Greenway connects the urban street blocks to various mountainous parks and suburban forest reserves through long-distance treetop walkways and other structures. It provides high-quality areas for citizens to hike, sightsee, and exercise. It is also the first successful attempt to introduce the long-distance treetop walkway into an urban built-up area. Thus, it has assumed a new role in urban public landscape design. Further, it has provided an inspiration for Chinese planners: The Fu Forest Trail, as representative of the projects in China, refers to the design and construction experience of the Alexandra Forest Walk in various respects.

\subsection{The Fu Forest Trail of China}

\subsubsection{Construction Overview}

The Fu Forest Trail (Figure 4) is the first elevated trail in China made entirely of steel. It shuttles through the dense mountainous forest of the Jinniu mountainous area of the Fuzhou urban district. The company known as Look Architects (Singapore) was predominantly responsible for the design work. The main route, with a length of $6.2 \mathrm{~km}$, adopts an elevated structure. There were also many kilometers of ground-based walkways built during the same period as an adjunct. The total length of the forest trail network is more than $19 \mathrm{~km}$, covering a mountainous forest area of $175 \mathrm{hm}^{2}$, and the construction area is nearly $48.7 \mathrm{hm}^{2}[59,60]$. The route connects more than 10 mountainous parks, with various supporting facilities such as the bird's-eye view sightseeing platforms, observation towers, teahouses, a tourist center, catering centers, and an upcoming business center with an area of $3 \mathrm{hm}^{2}$ (some facilities were reconstructed from small abandoned mines and bus parking lots).

At the beginning of 2016, a trial operating section was opened to the public for the first time. This aroused widespread social attention. It received an average of around 20,000 tourists daily during this period. In the first three days of the Spring Festival holiday of 2018, 194,000 people visited the area [22]. In August 2018, the project was completed, and at least 200,000 people living in the surrounding urban areas had fair and convenient opportunities to enter the forest through the ten entrances in the route for daily recreational activities. The Fu Forest Trail has made the Jinniu mountainous area the most popular urban forest in Fuzhou. 


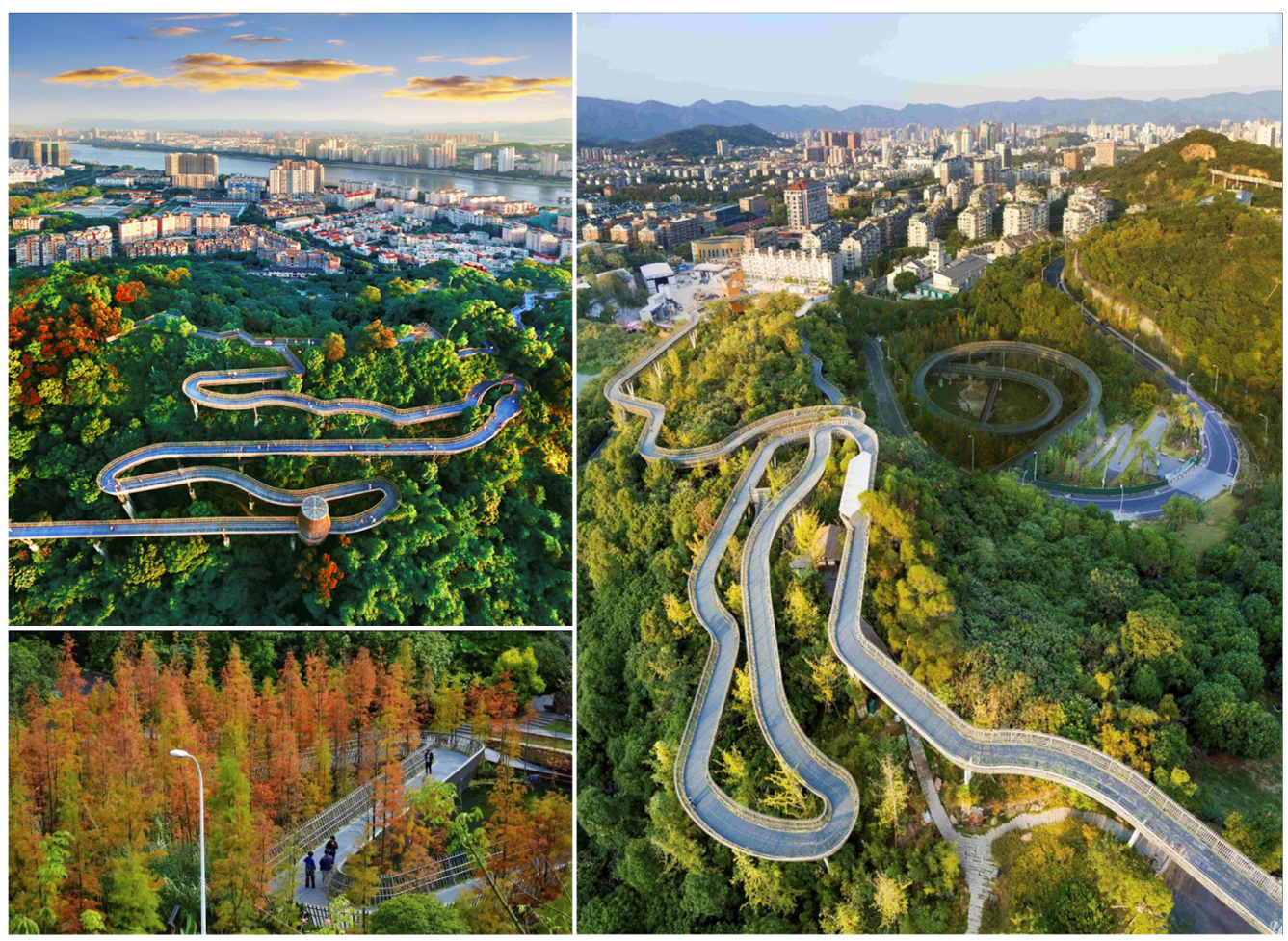

Figure 4. Photos taken from above the Fu Forest Trail.

\subsubsection{The Modular System and Elevated Structural Design}

It is difficult to install large construction machinery in the mountainous forest area of a city center. This is a problem that almost all the treetop walkway projects face. The architects proposed an innovative modular structure: basic prefabricated module combinations for easy transportation and assembly around the site. All modules could be systematically connected and dynamically adjusted.

As Figure 5 shows, an all-welded steel truss structure atop the walkway consists of seven modules: three junction modules, including " $\mathrm{L}_{1}$ " (a single-column straight junction module), " $\mathrm{L}_{2}$ " (a single-column curve junction module), and " $\mathrm{L}_{3}$ " (a double-column bending junction module). The Y-shaped columns are supported directly at the bottom of the junction modules. There are four segment modules: " $\mathrm{R}_{1}$ " (a linear segment module), " $\mathrm{R}_{2}$ " (a curved segment module), " $\mathrm{S}_{1}$ " (a leisure module with shade sheds and seats), and " $\mathrm{T}_{1}$ " (a viewing platform module with partial widening).

Flanges were used to consolidate the segment modules, mortise structures were used to link the junction and segment modules, and all the bolt holes between the sockets were hinged with high-strength bolts. In terms of slope control, the junction modules $\mathrm{L}_{1}, \mathrm{~L}_{2}, \mathrm{~L}_{3}$, and leisure module $S_{1}$ are flat, while segment modules $R_{1}, R_{2}$, and $T_{1}$ have a 1:16 (part of the flat slope) gentle slope. Visitors can thus easily stroll on the elevated walkway, as if on the ground. All steel modules were manufactured in the factory before being delivered to the destination for assembly. Therefore, to create the overall structure of the Fu Forest Trail, the modules were arranged in various ways and eventually combined into a walkway system that could be adapted to different terrains (Figure A3). The tree canopy walkway at Kirstenbosch National Botanical Garden adopted a similar construction technology: It is made entirely of galvanized steel components constructed offsite by Prokon Services at their workshop in Blackheath, and the giant pieces of this skeleton were then fitted together on site. This modular system simplified the complexity of the installation process and reduced adverse interference in the natural environment of the site. Thus, it has possible promotional value in future design practices. 
a)

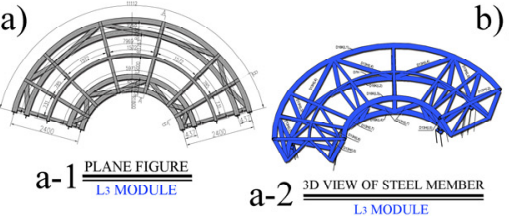

a- $1 \stackrel{\text { PLANE FIGURE }}{\frac{\text { L3 MODULE }}{\text { MODU }}}$

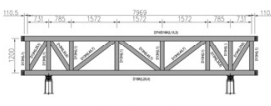

a-3 $\frac{\text { ELEVATION FIGURE }}{=\text { L3 MODULE }}$

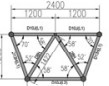
$\mathrm{a}-4 \frac{\text { SIDE SECTION (A-A) }}{\frac{\text { L3 MODULE }}{2}} \mathrm{a}-5 \frac{\text { SIDE SECTION (B-B) }}{\frac{\text { L3 MODULE }}{4}}$

d)

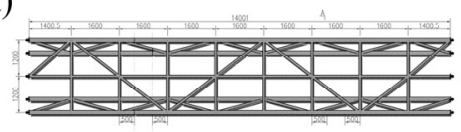

d-1 PLANE FIGURE

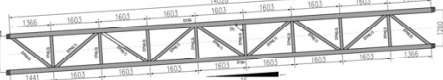

d-3 ELEVATION FIGURE

f)

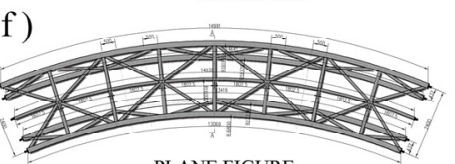

$f-1 \frac{\text { PLANE FIGURE }}{=\text { R2 MODULE }}$

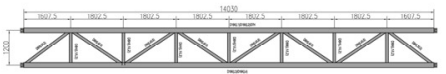

$\mathrm{f}-2 \stackrel{\text { ELEVATION FIGURE }}{=}$

g)
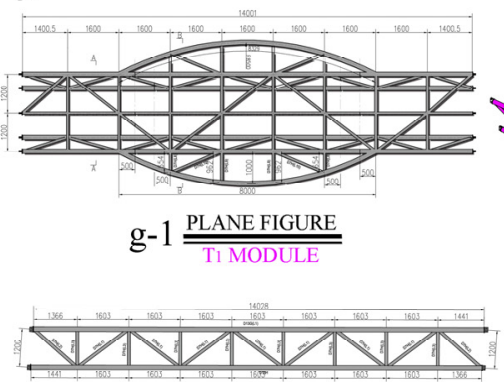

g- $2 \frac{\text { ELEVATION FIGURE }}{=\text { T1 MODULE }}$ b)

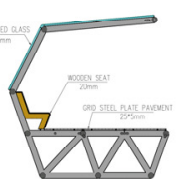

b- $1 \frac{\text { SIDE SECTION }}{\text { SI MODULE }} \quad$ b- $2 \frac{\text { SECTION OF STEEL MEMBER }}{\frac{\text { SI MODULE }}{2}}$

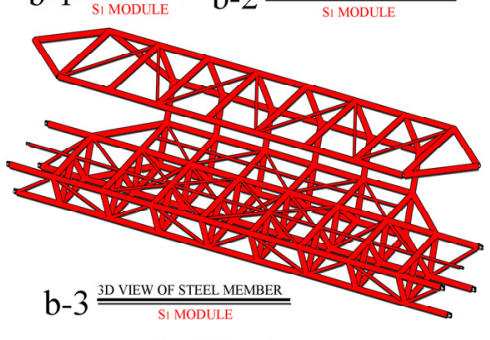

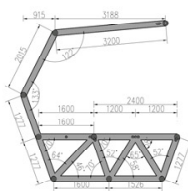

c)

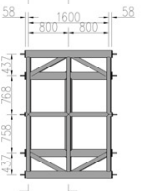

C-1 $\frac{\text { PLANE FIGURE }}{=}$

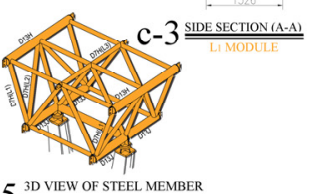

$-5 \stackrel{\text { 3D VIEW OF STEEL MEMBER }}{=}$

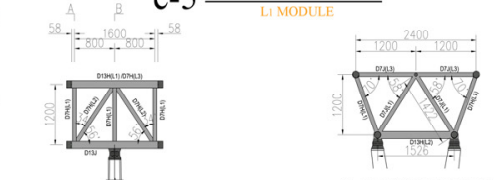

c-2 $\stackrel{\text { ELEVATIUN HIGURE }}{=}$

C-4 $\stackrel{\text { SIDE SECTION (B-B) }}{=}$

e)

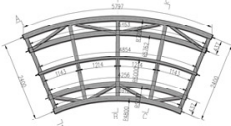

e-1 $\stackrel{\text { PLANE figure }}{=}$

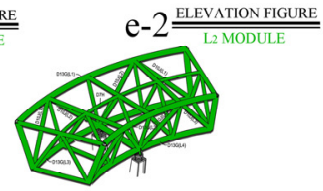

e-3 3D VIEW OF STEEL MEMBER

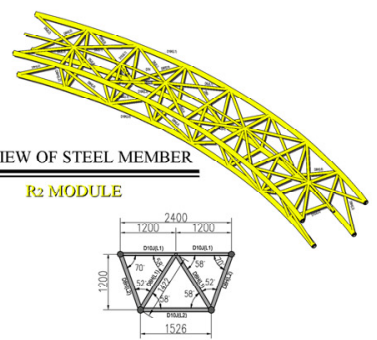

$$
\mathrm{f}-4 \frac{\operatorname{SIDE} \operatorname{SECTION}(\mathrm{A}-\mathrm{A})}{=\text { R2 MODULE }}
$$

\section{LEGEND}

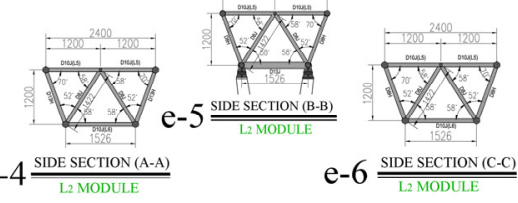

$\square$ Sı: leisure module with shade sheds and seats

$\square$ L1: single column straight junction module

$\square$ L2: single column curve junction module

$\square$ L3: double columns bending junction module

$\mathrm{T} 1$ : viewing platform module with partial widening

$\mathrm{R} 1$ : linear segment module

R2: curve segment module

$\mathrm{g}-3 \frac{\text { 3D VIEW OF STEEL MEMBER }}{=\text { TI MODULE }}$

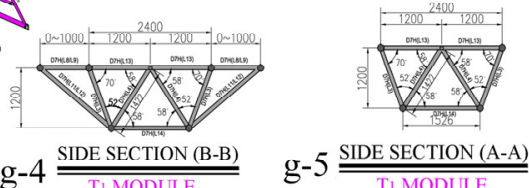

Figure 5. The structural design drawings of seven modules of the Fu Forest Trail: (a) The $\mathrm{L}_{3}$ module; (b) the $\mathrm{S}_{1}$ module; (c) the $\mathrm{L}_{1}$ module; (d) the $\mathrm{R}_{1}$ module; (e) the $\mathrm{L}_{2}$ module; (f) the $\mathrm{R}_{2}$ module; and ( $\mathrm{g}$ ) the $\mathrm{T}_{1}$ module (Source: author remade according to reference [22]).

Just as with the Kew Garden of London, the Y-shaped column under the walkway platform, assembled with invisible nuts and bolts, imitates the simplified shape of tree branches. However, the site topography of Kew Garden varies only slightly, the supporting piers of the Fu Forest Trail are more complicated in design. To match the heights of the walkway platforms, the architects designed ten column forms and chose the most suitable column at any time among them based on the changes of terrain. Y-shaped columns with concrete bases (Figure 6a) are used over $3 \mathrm{~m}$ above the ground (six types, Types A to F), and steel structure columns (Figure 6b) with pile caps were used for the spans less than 3 
$m$ above the ground (Types X1 to X4). The base of the column is embedded to a depth of 1.2-1.5 $\mathrm{m}$ below the ground to ensure the stability and safety of the entire structure.

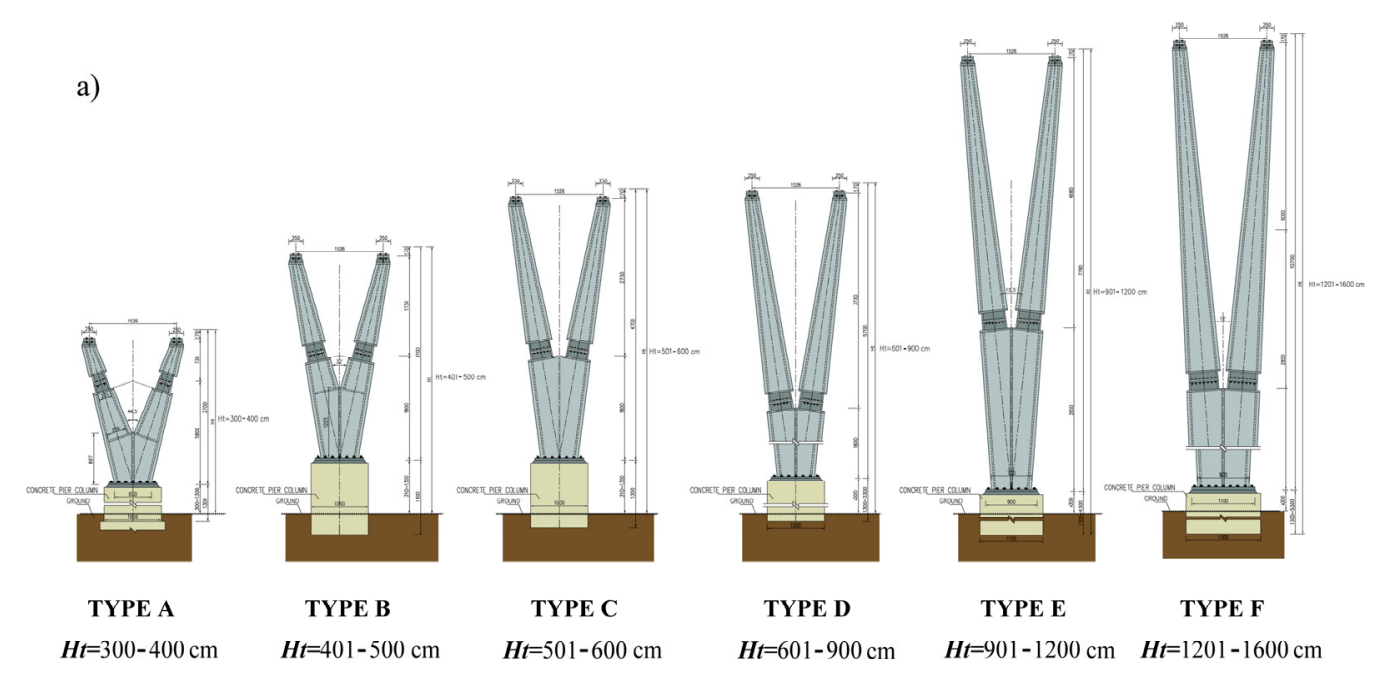

b)

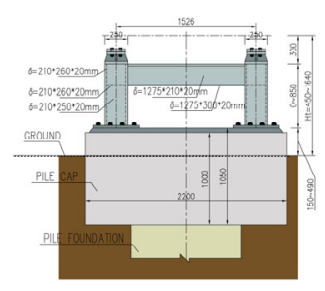

TYPE X4

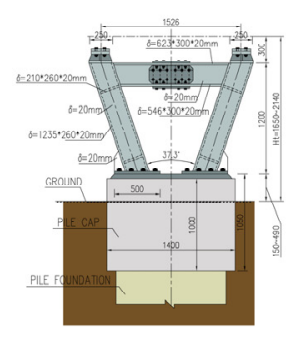

TYPE X3

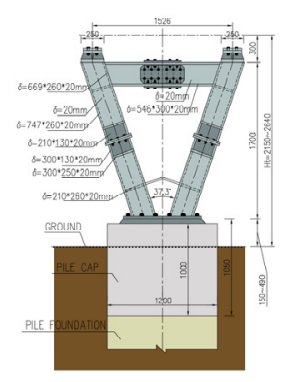

TYPE X2

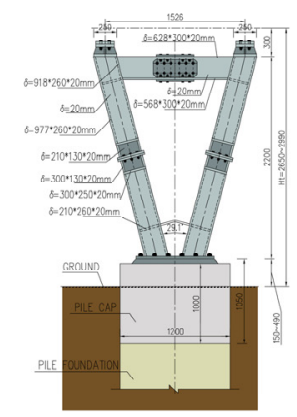

TYPE X1

$H \boldsymbol{t}=265-299 \mathrm{~cm}$

Figure 6. Various columns for the support structure of the Fu Forest trail: (a) the Y-shaped columns, with six types (Type A to F); (b) the steel structure columns, with four types (Type X1 to X4) (Source: author's work).

\subsubsection{Design Appearance and Construction Materials}

With its rhythmic curves, the Fu Forest Trail presents the public with a flexible, creative, futuristic, and expressive visual impact.

We can examine several important nodes in the route as examples. First, the north of Jinniu Sports Park houses the huge spiral staircase entrance, with $210 \mathrm{~m}$ of loop length; its outer ring measures $24 \mathrm{~m}$ in diameter, while its inner ring measures $18 \mathrm{~m}$. Occupying limited space, the spiral design not only meets the basic needs of users but also reduces the volume and span of the entrance structure (Figure 7a). A similar design appears in the Meifeng Mountainous Park section. The designers built the elevated trail above the lake by means of the spiral circular winding of the steel truss. Some columns are directly fixed in the lake water, allowing walkway platform to get closer to the lake, allowing tourists to comfortably enjoy the lake landscape with a different perspective while walking above the water (Figure $7 \mathrm{~b}$ ). Further, for the public to enter the main line of the forest trail directly instead of crossing the crowded motor vehicle lane against traffic flow, an unsupported overhead bridge spanning $72 \mathrm{~m}$ (Figure 7c) was built as an overpass of the Honggan Road [20,22]. 
a)

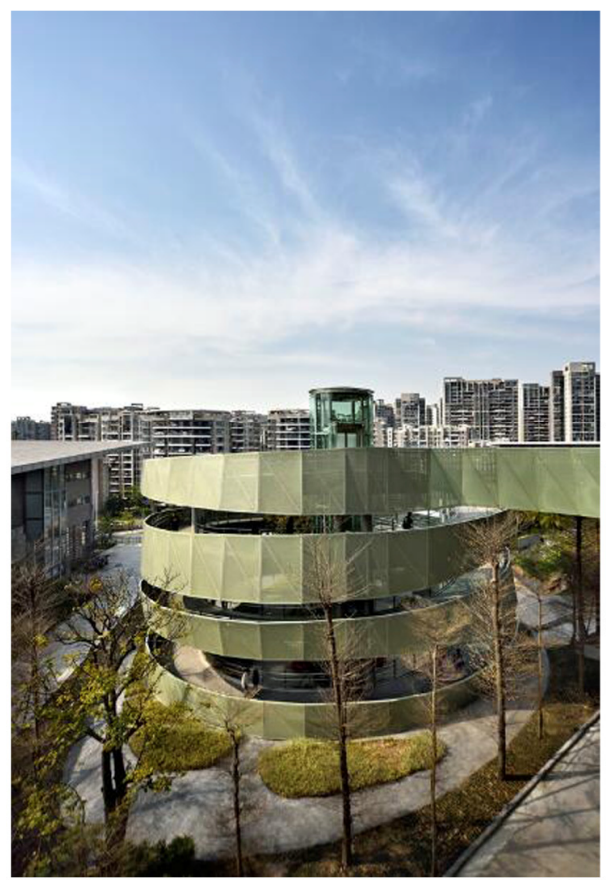

b)

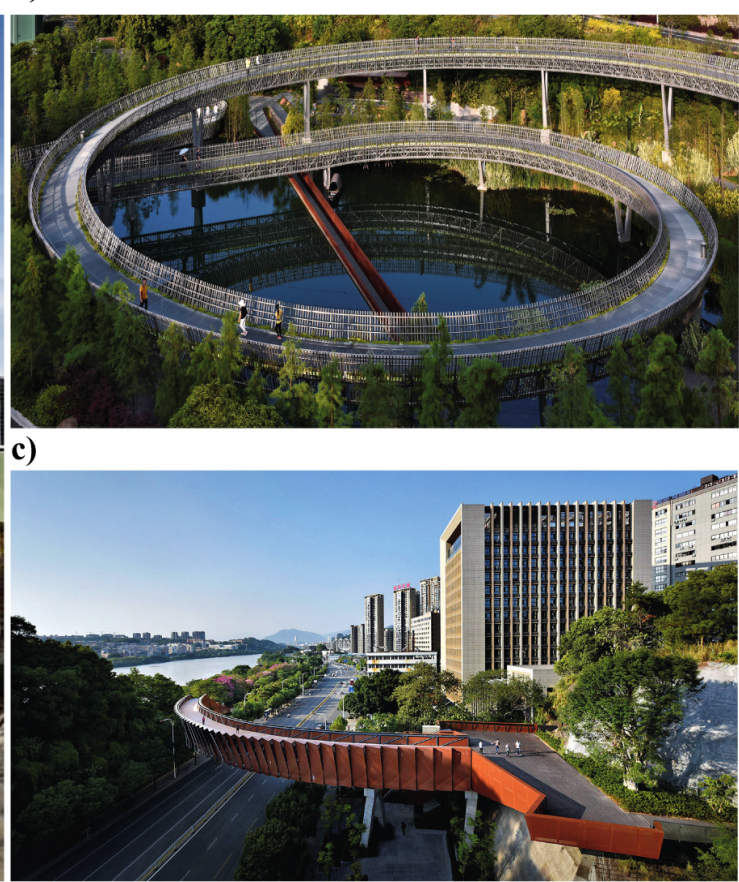

Figure 7. Three locations depicting the outstanding designs of the Fu Forest trail: (a) The huge spiral staircase entrance in the north of Jinniu Sports Park; (b) the elevated trail above the lake, the spiral circular winding of the steel truss, in the Meifeng Mountainous Park section; and (c) the unsupported overhead bridge in the Honggan Road section (Source: author remade according to reference [22]).

In addition to the eye-catching landmark of the route, each section of the Fu Forest Trail has its own characteristics that combine with the site's landform and geomorphology to create a design with a continuous and futuristic expression. Moreover, materials made entirely of galvanized steel have a design lifespan of more than 30 years and are recyclable and sustainable.

\subsubsection{Details}

According to the barrier-free walking standard, the bridge deck was paved with $25 \times 5 \mathrm{~mm}$ steel grating plates at intervals of less than $1.5 \mathrm{~cm}$, which can meet the diverse needs of people (including the disabled) for leisure, fitness, and sightseeing. A rest pavilion or shade pavilion was set up every $200 \mathrm{~m}$ along the forest trail to facilitate resting and enjoying bird's-eye views. The elevated walkway was connected to the ground-based walkways, climbing stone steps, bicycle lanes, and gyroidal vehicle lanes to form a ring network enabling visitors to move freely and quickly in the mountainous area. In areas with a significant height difference, vertical elevator provide convenience and shortens the detour time.

\subsubsection{Other Supporting Facilities}

These include the following:

- The main entrances, exits, and landscape nodes of the trail are equipped with many touch screens and LED display screens that provide information such as introductions to scenic spots, popular science explanations on plants and mountain ecology, convenient service inquiries, PM 2.5 numerical display, and real-time broadcasts of temperature and humidity.

- In the rest platform and visitor service centers covered by a $4 \mathrm{G}$ wireless network, tourists can comment on the Fu Forest trail service management and sightseeing experience on the official website at any time. 
- All entrances and exits are equipped for daily video monitoring, intelligent analysis, and passenger flow statistics. The information system also integrates functions such as one-click help, emergency broadcast, and forest fire monitoring.

- In 2019, the LED lighting system of the trail was completed, allowing citizens to enjoy night scenes in the forest (Figure A4).

\subsubsection{Construction Treatment for Minimum Environmental Interference}

The greatest degree of protection for the natural environment and biodiversity is always an important consideration in treetop walkway design practices. First, in the case of the Alexandra Forest Walk and the Fu Forest Trail, the distance between columns was designed to be as wide as possible so as to minimize damage to the surface vegetation. The average distance between columns of the Fu Forest Trail is $14.4 \mathrm{~m}$, which is the longest yet built, and the use of single supporting piers minimizes the foundation's surface while greatly reducing the adverse impact on the ground vegetation. Second, the hollowed-out walkway grid plate will not block the sunlight for ground plants. Moreover, during the construction of the trail, to reduce the impact of large-scale engineering equipment on forest vegetation (besides transporting materials by hand, mule, and cable), the construction team developed two patented technologies: the "bridge deck crane" and "sliding hoisting". Thus, the constructed bridge deck was used as a track platform to transport heavy equipment or steel components that had to be assembled, so that the lifting equipment and large steel components did not need to be transported on the ground, reducing the damage to plants during construction.

\subsection{Other Elevated Forest Trails in China}

Unlike the profit-oriented projects in Australia or European countries, most of the treetop trails in China are located in urban forest areas and were designed or constructed by government planning departments as free public facilities. The main purpose of construction is to provide better forest recreation areas for citizens, create equitable recreational opportunities, improve the livability of the city, coordinate urban planning, and promote the construction of urban greenway. Such a functional orientation has become a trend because the government is fully willing to make huge financial investments for healthy public lifestyles and to improve the environment. By 2020, China built eight long-distance canopy trails on which hundreds of millions of dollars were spent. Public feedback has been positive. For example, before 2015, Jinji Mountainous Park was still a semi-closed area and few citizens would enter the forest area for recreation. However, the tourist flow volume of the Park rose rapidly after the construction of the $2.7 \mathrm{~km}$ "City Viewing Plank Road" (Figure A5). In a statistics survey of the tourist flow volume conducted by Fuzhou Gardens Bureau from 18 to 24 April 2016, the total numbers of tourists of Jinji Mountainous Park was rated the fourth (Figure 8) of the 28 major parks or public green spaces of the city. Thus, the new walkways have attracted citizens to the natural environment and changed citizens' recreational habits to a significant extent [61-63].

Chinese planners also deliberately use long-distance walkways to connect urban nodes or green spaces and create a comprehensive linear recreation system and multifunctional urban public landscape for the elevated forest walkway, and hence the length of the footpath is constantly increasing. The Xiamen Mountains-to-Sea Trail (Figure 9), completed in 2020, spans a total length of $23 \mathrm{~km}$, of which over $10 \mathrm{~km}$ are elevated, making it the longest treetop walkway in the world. A total of eight urban forests and three urban inner lakes are connected by the trail with docks, beaches, parks, small exhibition halls, museums, healthcare centers, and temples. It is equipped with enriching recreational service facilities and many intelligent devices. The 52 entrances and exits set up along the route allow citizens to enter and exit the trail freely [57]. 


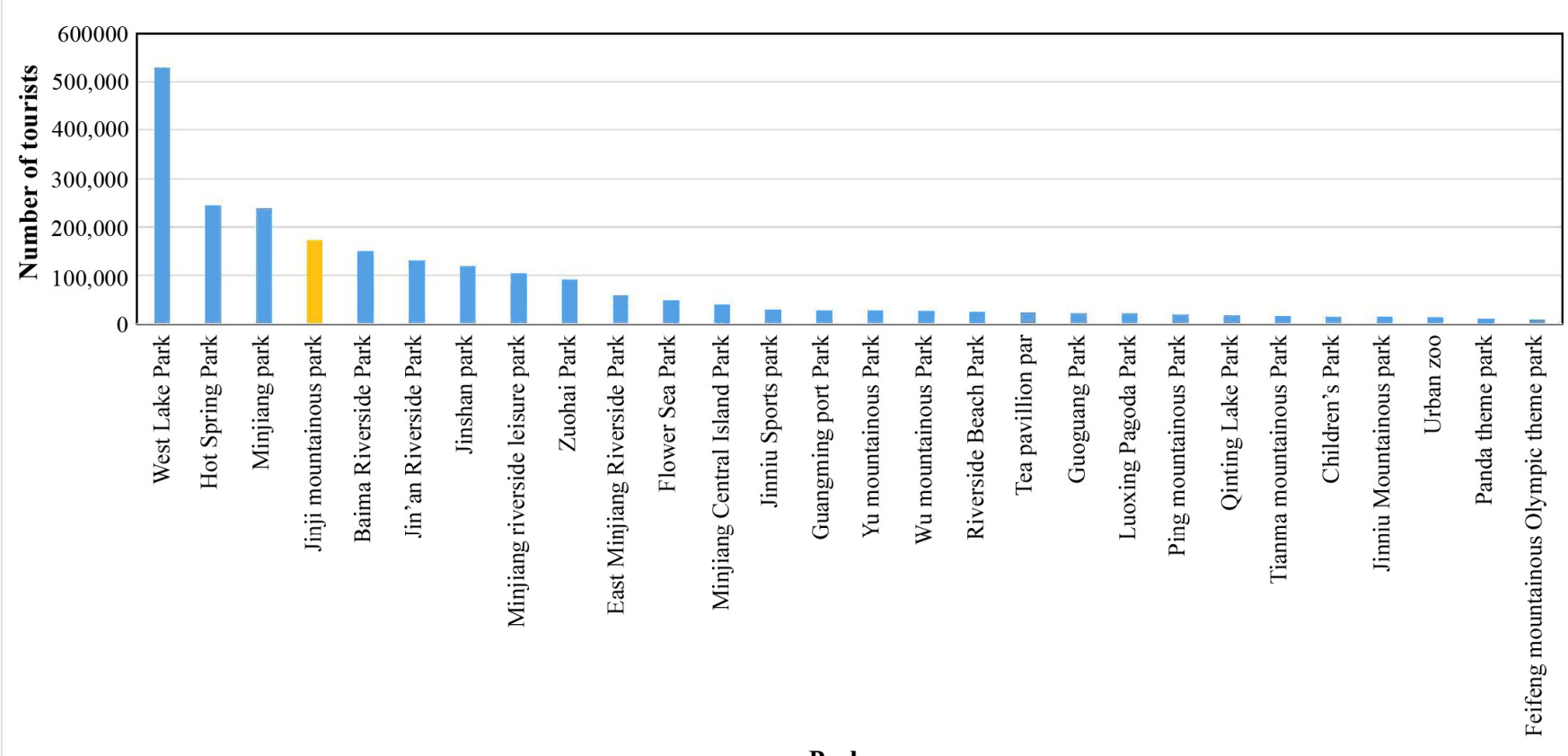

Parks

Figure 8. The statistics on the total number of visitors in each parks of Fuzhou during the investigation (Source: author remade according to reference [63]). Note: The statistics of the tourist flow volume were collected from 6:00 on 18 April to 18:00 on 24 April 2016).
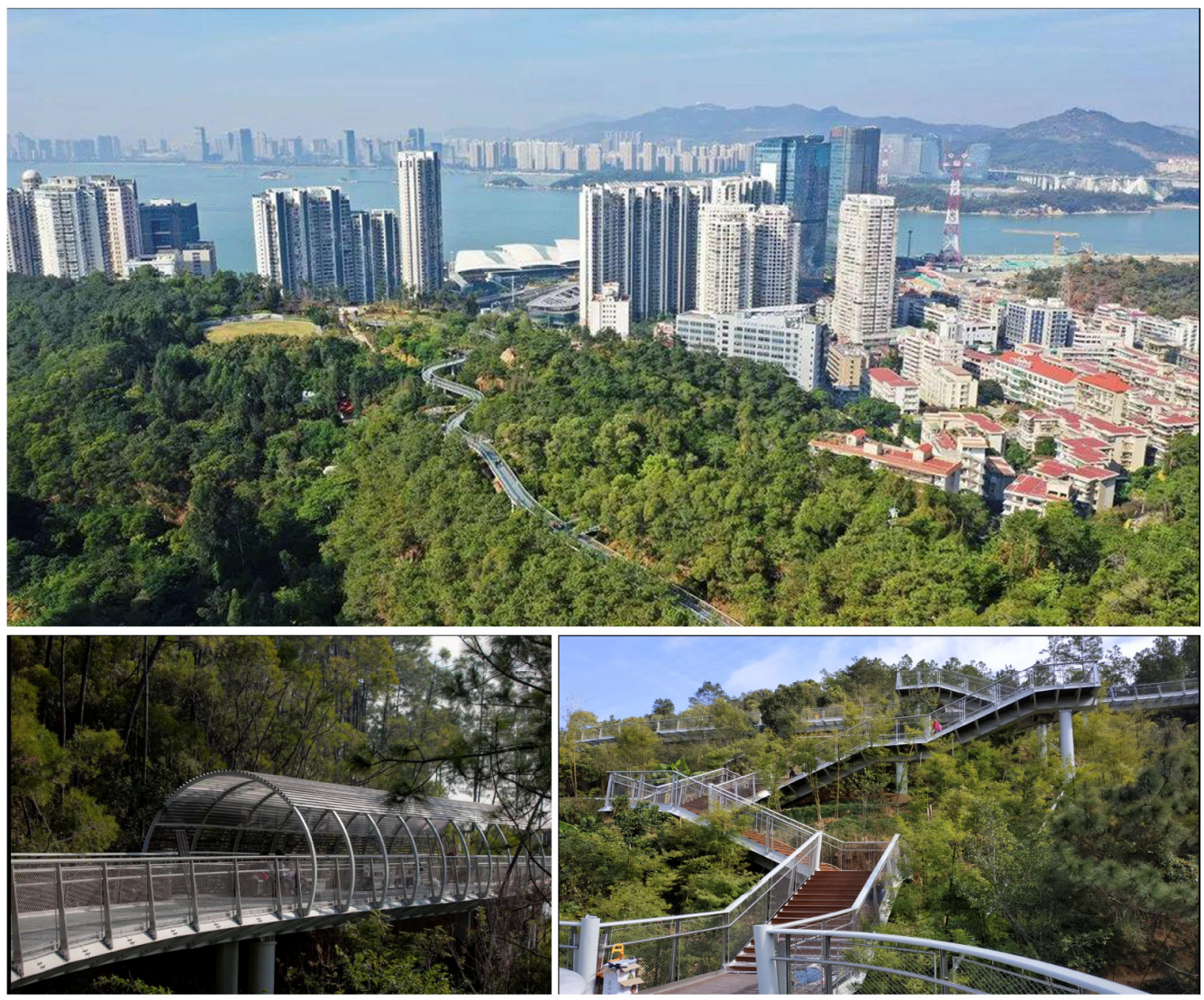

Figure 9. Photos of the Xiamen Mountains-to-Sea Trail. 


\section{Discussion}

\subsection{Particularities and Advantages of Architectural Structures}

\subsubsection{Adequate Room for Design Creation and Improvement}

From the first public opening of treetop walkways, designers have been committed to constantly improving almost every aspect of their design, including its shape, structure, materials, and construction methods. The initial structures (similar to a suspension bridge) did not have stable support foundations and reliable material sources. Currently, standardized components, sturdy materials, standard construction processes, and even exquisite night lights are used for layout planning. Compared to the ground-based forest trails built with stone steps, the integration of architectural structures adds many possibilities to treetop walkway designs. In limited forest spaces, designers could deepen the environmental perceptions of users by adjusting the length of the recreational route or changing the height or angles of the elevated walk planes, creating art works with visual impact through complex geometries, and opting for aesthetic design through innovations in appearance, structure, or materials. Designers are beginning to understand how to combine the disciplines of architecture and exhibits to create an advanced design catering to public changes in aesthetic perception [64].

The Limb-Tree Canopy Walk of Morris Arboretum, University of Pennsylvania (Figure 10), is one of the most elaborate canopy walkways. The design team not only built a more circuitous path with a zig-zagging walkway that offers a series of opportunities to enjoy the vistas, but also incorporated a hanging viewing pavilion that imitates birds' nests. It is made of natural tree-derived materials, and some areas incorporate the characteristics of Japanese and Chinese gardening and architecture into the structure [65]. Similarly, Rotorua Redwoods Treewalk (Figure A6) is a design-oriented forest tourism project in New Zealand. Visitors traverse the gaps between majestic 120-year-old redwood trees by a 700 meters long suspended walkway that provides breathtaking and stunning views from a bird's-eye perspective during the daytime. Visitors can enjoy an iconic nocturnal tourism experience at night too, with the Redwoods Nightlights created by a professional lighting design team [66].

a)

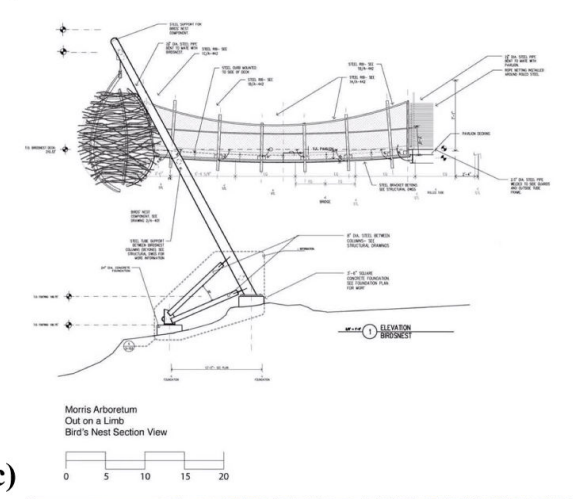

b)

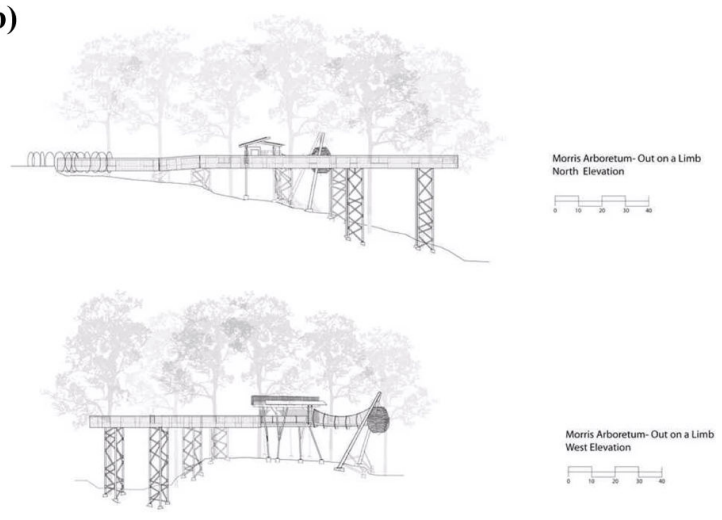

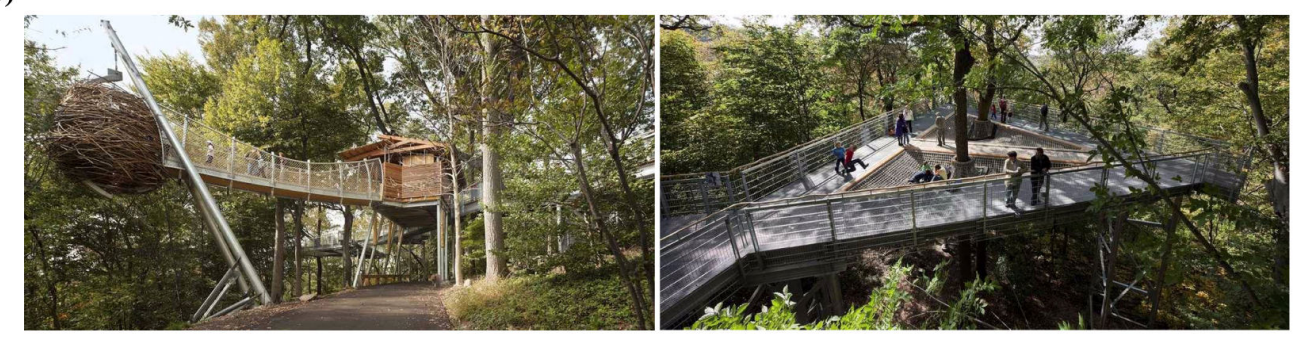

Figure 10. The Limb-Tree Canopy Walk of Morris Arboretum, University of Pennsylvania: (a) The section view of a hanging viewing pavilion that imitates birds' nest, (b) the side elevations of the walkway, and (c) walkway photos (Source: https:/ / www.archdaily.com/95781/morris-arboretumtree-adventure-metcalfe-architecture-design, accessed on 31 July 2021; and reference [65]). 
It is important that such design upgrades obtain recognition and acceptance easily, from the public or more professional evaluation teams. According to research on the Fu Forest Trail $[16,59,60]$, appearance design has a high degree of acceptance by local residents, more than $70 \%$ of respondents think that the appearance and shape of the trail possess a high level of design and an aesthetic feeling. The trail has also won various international awards for its architectural design and in inhabitation environment $[20,22,60]$.

\subsubsection{Improved Adaptability for Complex Terrains}

Compared to the ground-based mountainous trails, treetop walkways are better able to cope with the complex elevational changes of mountainous terrain. Ground-based trails are always limited by the terrain and often cannot provide the best viewing experience or a bird's-eye view for visitors. Canopy trails allow greater freedom for route planning and significantly improve the recreational value of sightseeing. In particular, with the adoption of the modular system, designers can adjust the combinations of modules and the height of supporting structures in advance to achieve the maximum fit to varying terrains and overcome barriers. Furthermore, their designs seldom sacrifice the comfort and trafficability of users. The bridge decks have gentle slope changes with as few steps as possible, making them suitable for disabled people in wheelchairs or parents pushing baby carriages, as they can walk on a walkway suspended several dozen meters in the air just as easily as on the ground [57]. For example, the ratio of slope height to horizontal length is limited to less than 1:16 in the Fu Forest Trail, no matter how the terrain changes, and the maximum gradient range of projects in Europe is 2-6\% (Figure A7).

\subsubsection{Unique Recreational Experiences}

The unique overhead structure and the undulating slope changes of the sites of these walkways have had effects on the public viewing field, aesthetic impression, touch, and enjoyment when walking, creating a completely different perception from the groundbased trails, including visual, tactile and psychological experiences. The numerous treetop walkways in Australia, New Zealand, and forest tourist areas of Europe deepen the viewing experience through a combination of elevated bridge decks and super-high viewing platforms. Research on the perceptions and experiences of the Fu Forest Trail $[17,60,64,67]$ has found the public to report a significant preference for and recognition of the enjoyment generated from the above-ground structures. The overall microclimate effect of the trail is better, with a positive effect on one's physical comfort and enjoyment $[68,69]$, and the public has gained strongly positive experiences of the sightseeing (e.g., vivid viewing angles, surprising urban skylines from bird's-eye view) [59,60], tactile sensations, and textures of the construction materials of the trail [60].

\subsubsection{Lower Developmental Impact on the Ecological Environment}

In nature reserves and ancient forest areas, the ecological environment through which trails pass are often primitive and fragile. Compared to ground-based forest trails, treetop trails often do not entail drastic transformations of the original terrains. The contact areas between the building foundations and the ground are usually small, and the pedestrians cannot damage the precious "exhibits" in the forest areas easily because they cannot also leave the trails casually [70]. Maximum protection of the natural environment and biodiversity remains an important consideration in design practice, with extremely strict requirements for environmental protection during development; therefore, the design and construction of the trail must ensure a minimum impact on the ecosystem and be integrated with its the surroundings where possible. In the Royal Forest of Salcey, to protect the rare orchid species on the ground and the endangered great crested newts living in the ponds, a separate team of consultants was appointed by the Forestry Civil Engineering Department in the U.K. to carry out all necessary measures to ensure attention to environmental protection before the walkway construction could start. In the process of construction, the contractor was required to conduct a close check daily and be ready to facilitate random 
visits from "Natural England," an environmental supervision department-if any newts died during the construction, this could have caused a 9-week delay [39].

\subsection{Urban Public Landscapes: A Link Connecting Residents with the Environment}

Landscapes are the medium of communication between humans and the natural environment, and between individuals and others. From this viewpoint, it can serve to convey countless potential values [71]. The design practices of nearly five years show that treetop walkways are progressing beyond the scope of a single architectural design to be regarded gradually as a benign intervention in urban development through the medium of the urban public landscape. Therefore, they carry multi-level and cross-domain social values and missions.

In 2015, Fuzhou was ranked the world's 10th fastest growing metropolitan area by the Brookings Institution [22]. This rapid economic development has brought about many complex environmental and social issues. Among them, the contradiction between the rapid development of cities and protection of mountainous and forest areas is the most acute. Flat terrain is often more suitable for residential and developmental purposes; however, mountainous and hilly terrain accounts for $72.68 \%$ of the Fuzhou urban area, leading to higher costs and greater restrictions on development in the urban mountainous areas. During the past half century, the municipal government and planning department issued various mountain protection plans (Secondary planning of Fuzhou Urban Master Plan, 1958, 1984, 1998, and 2008), but most of them still adopted the policy of closed management of mountainous forest areas. The mountains were divided, enclosed, and isolated by an increasing number of buildings, and some of the less prominent mountains disappeared during rapid urban constructions. Mountains were no longer a symbiotic and integrated entity with the city, but were distant from citizens' daily lives [72].

Urban managers and local researchers have explored new strategies that can develop, protect, and benefit peoples' livelihoods. This significant change in planning ideas occurred after 2008, when the successful practice of Alexandra Forest Walk provided Fuzhou planners with the idea of establishing an elevated slow-walking system adapted admirably to the mountainous terrain. Urban managers planned to redevelop the mountains of the central area through modern forest walkways, just as with the Southern Ridges of Singapore, to provide citizens with new recreational areas for sightseeing, exercise, and mountain climbing, and opportunities to get close to the natural environment. Consequently, the organization that designed the Alexandra Forest Walk, Look Architects, was invited to undertake the development of urban forest trails in the Jinniu Mountainous Area.

The Fu Forest Trail has become a unique landmark within the city center. Additionally, it is fulfilling the mission of a urban public landscape, linking the residents with their natural environment. Since it provides ideal public accessibility, it has altered people's recreational habits to a certain extent, facilitating healthy lifestyles and allowing residents a dose of environment. In the overall plan of the Fuzhou greenway network (2013), 16 hilly greenways spanning a total length of $160 \mathrm{~km}$ will rely on the elevated walkway as the main connecting structure. This is planned to be established in the next 5-10 years in the urban mountainous and forest areas [73]. The core value of the treetop walkway has been recognized and promoted by certain mountainous and hilly cities in the southeast of China because it provides a new perspective on benign urban interventions.

\subsection{Research Directions}

Despite many forest walkways in existence, insufficient attention has been paid by the academia to this unique form of trail-building, and its theoretical research foundation remains weak. We recommend that improvements in elevated forest walkways must be studied through urban planning, architecture and landscape architecture, forest management, tourism, and other disciplines. Possible directions of study are presented below.

1. Cost reduction and building material improvements: An elevated forest walkway is significantly more expensive than a trail on the ground. This constitutes an obstacle to 
its future promotional process. For example, the STIHL treetop walkway of Westonbirt National Arboretum, which spans 300 m, cost GBP 1.9 million to build [74,75]; Kew Treetop Walkway was made from over 400 tons of weathered steel [43]; after more than eight years of design and construction, the Adirondacks Wild Walk with $390 \mathrm{~m}$ cost 84 tons of steel and US\$ 5.5 million [76]; the Alexandra Forest Walk of Singapore and other Chinese city projects also cost millions of dollars. Once such a trail is included in urban greenway planning, it spans a longer distance and has higher safety requirements, making trail-building structures significantly more complex, needing higher steel consumption. Thus, the simplification of its structural design requires more advanced technologies, durable and cheaper materials, and in-depth research in structural engineering [77].

2. Optimization of recreational experiences and potential of recreational value: A targeted improvement will certainly hold rich returns for profit-oriented projects. Some research institutions in Australia have carried out information collection research of tourists, based on some early cases like O'Reilly's Treetop Walk and Valley of the Giants Treetop Walk. However, some new cases worldwide have not been further studied. In the past 20-30 years, the preference and recreational behavior of tourists are changing over time. More comprehensive systems for data collection, processing, and evaluation of tourists' experiences and feedback should be instituted with faster and more advanced design improvements for recreational experiences, as well as tourism management support and architecture improvements.

3. A harmonious coexistence between humans and the environment: Although many commendable measures have been taken, a lot of potential exists in the protection of urban mountainous forest areas, involving how to carry out a more definite and feasible plan regarding sustainable development in urban mountainous and forest areas based on the elevated walkway system, and more efficient measures to minimize interference in the environment during construction. Some issues need to be considered, such as the negative impact of the night lighting on wildlife, especially the LED night lighting are disastrous for birds and phototactic insects.

4. Planning and design: This includes elevated structural designs, design appearance, tourism route planning (e.g., determining the best tourist route based on the Geographic Information System), utilization of the urban greenway network, and the design of night lighting.

5. Tourism operation and management: This includes the application of intelligent devices, day-use facilities, upgrades, visitor safety improvements, better trail-side guidance and sign systems, science popularization, and interpretive sign systems.

\section{Conclusions}

The study employed a narrative approach to introduce and provide an overview of, treetop walkways and their novel features. It collected and discussed practical information, explored the social value of treetop trails in the harmonious coexistence of humans in their environment, and considered their particularities and advantages. We confirmed that: the design of these walkways impacts various fields and groups of people. Therefore, understanding suitable designs helps the environment, disadvantaged groups, forest management policymakers, and environmental researchers. The study also analyzes how the design allows the natural environment to remain unharmed from unnecessary traversing through the ground trails, and thus assists researchers.

To the author's knowledge, there has been no previous comprehensive review of this unique trail-building topic. Thus, elaboration and reference points of this study could fill the gap in previous research, assist interested scholars in understanding elevated forest trails, and serve as an inspiration to city planners.

Moreover, in the process of continuous improvement and application practices, treetop walkways have been transformed from cross-border designs that couple architectural structures and forest trails into an urban public landscape conveying a wide range of multi- 
level social values. The Fu Forest Trail is a typical case. We explored it in as much detail as possible in this article; numerous pictures and information are provided. We figured that it is an excellent creative and innovative engineering example under the framework of strict design principles to benefit the public and realize the perfect combination of functional design and engineering efficiency. As a milestone of urban public landscape design, the Fu Forest Trail can be a reference case that many mountainous and hilly cities can follow. Meanwhile, we hope that even more excellent designs come up to meet the increasing forest recreational needs and help bridge the distance between people and their environment.

Author Contributions: Conceptualization, Y.K., Y.L., and B.L.; validation, Y.K., Y.L., and Q.C.; investigation, Y.K., Y.L., X.G., and B.S.; resources, Y.K., Y.L., and J.L.; writing-original draft preparation, Y.K. and Y.L.; writing-review and editing, Y.K.; visualization, Y.K.; supervision, Q.C. and B.L.; project administration, Y.K.; funding acquisition, Y.L. and B.L. All authors have read and agreed to the published version of the manuscript.

Funding: This research was funded by the Educational Research Project of Fujian Provincial Education Department [grant number JAT200366]; the High Level Talents Fund of Fujian Jiangxia University in 2020 [grant number 8002/00140170]; and the Key Project of Science and Technology in Fujian Province [grant number 2018NZ0002-2].

Institutional Review Board Statement: Not applicable. This study is not involving humans or animals. Informed Consent Statement: Not applicable.

Data Availability Statement: Data are contained within the article.

Acknowledgments: The authors would like to appreciate the Key Lab for Geomatics Technology and Optimize Resources Utilization in Fujian Province for providing the support on investigation in the past three years.

Conflicts of Interest: The authors declare no conflict of interest. The funder had no role in the study.

\section{Appendix A}

Table A1. Basic information about global treetop walkways.

\begin{tabular}{|c|c|c|c|c|c|c|c|c|c|c|}
\hline \multirow[b]{2}{*}{ No. } & \multirow[b]{2}{*}{ Name } & \multirow[b]{2}{*}{$\mathrm{OT}^{*}$} & \multirow[b]{2}{*}{ Location } & \multirow[b]{2}{*}{$E L *(m)$} & \multirow[b]{2}{*}{$\mathrm{MSH}^{*}(\mathrm{~m})$} & \multicolumn{4}{|c|}{ Main Uses } & \multirow{2}{*}{$\begin{array}{c}\text { Designers/ } \\
\text { Contractors/Owners }\end{array}$} \\
\hline & & & & & & CFTP * & FRF $^{*}$ & UPL * & UMG * & \\
\hline 1 & $\begin{array}{l}\text { O'Reilly's Treetop } \\
\text { Walk }\end{array}$ & 1987 & $\begin{array}{c}\text { Lamington National Park, } \\
\text { Australia }\end{array}$ & 160 & 16 & & $\sqrt{ }$ & & & \\
\hline 2 & $\begin{array}{c}\text { Valley of the } \\
\text { Giants Tree Top } \\
\text { Walk }\end{array}$ & 1996 & $\begin{array}{l}\text { Walpole-Nornalup } \\
\text { National Park, } 430 \mathrm{~km} \\
\text { south of Perth, Western } \\
\text { Australia, Australia }\end{array}$ & 600 & 40 & $\sqrt{ }$ & & & & WATC., DALM. \\
\hline 3 & Tahune Airwalk & 2001 & $\begin{array}{c}\text { Tahune Forest, Hobart, } \\
\text { Tasmania State, Australia }\end{array}$ & 620 & 30 & $\sqrt{ }$ & & & & Canopy 01 \\
\hline 4 & $\begin{array}{l}\text { Otway Fly Treetop } \\
\text { Walk }\end{array}$ & 2003 & Melbourne, Australia & 600 & 30 & $\sqrt{ }$ & & & & Canopy 01 \\
\hline 5 & $\begin{array}{l}\text { Sungai Sedim } \\
\text { Treetop Walk }\end{array}$ & 2004 & $\begin{array}{c}\text { Sedim River Recreation } \\
\text { Park, Sungai Sedim } \\
\text { Amenity Forest, Kedah, } \\
\text { Malaysia }\end{array}$ & 925 & 50 & & $\sqrt{ }$ & & & \\
\hline 7 & $\begin{array}{l}\text { Salcey Treetop } \\
\text { Walkway }\end{array}$ & 2005 & $\begin{array}{l}\text { The Royal Forest of Salcey, } \\
\text { Northamptonshire, UK }\end{array}$ & 300 & 20 & & $\sqrt{ }$ & & & $\begin{array}{l}\text { Forestry Civil } \\
\text { Engineering } \\
\text { Department }\end{array}$ \\
\hline 8 & $\begin{array}{l}\text { 'Promenoir des } \\
\text { Cimes' L'Escaut } \\
\text { Plain Natural Park } \\
\text { Treetop Walkway }\end{array}$ & 2006 & $\begin{array}{l}\text { Atop the mountain in } \\
\text { L'Escaut Plain Natural } \\
\text { Park, Bonsecours, France }\end{array}$ & 60 & 16 & & $\sqrt{ }$ & & & Arcadus Architects \\
\hline 9 & $\begin{array}{l}\text { Kew Treetop } \\
\text { Walkway }\end{array}$ & 2008 & $\begin{array}{l}\text { Royal Botanic Garden of } \\
\text { London, UK }\end{array}$ & 200 & 18 & & $\sqrt{ }$ & & & $\begin{array}{l}\text { Marks Barfield } \\
\text { Architects }\end{array}$ \\
\hline 10 & $\begin{array}{l}\text { The Greenheart } \\
\text { TreeWalk }\end{array}$ & 2008 & $\begin{array}{l}\text { UBC Botanical Garden, } \\
\text { Vancouver, Canada }\end{array}$ & 310 & 20 & & $\sqrt{ }$ & & & $\begin{array}{c}\text { University of British } \\
\text { Columbia }\end{array}$ \\
\hline
\end{tabular}


Table A1. Cont.

\begin{tabular}{|c|c|c|c|c|c|c|c|c|c|c|}
\hline \multirow[b]{2}{*}{ No. } & \multirow[b]{2}{*}{ Name } & \multirow[b]{2}{*}{ OT * } & \multirow[b]{2}{*}{ Location } & \multirow[b]{2}{*}{$\mathrm{EL}^{*}(\mathrm{~m})$} & \multirow[b]{2}{*}{$\mathrm{MSH}^{*}(\mathrm{~m})$} & \multicolumn{4}{|c|}{ Main Uses } & \multirow{2}{*}{$\begin{array}{c}\text { Designers/ } \\
\text { Contractors/Owners }\end{array}$} \\
\hline & & & & & & CFTP * & FRF * & UPL * & UMG * & \\
\hline 11 & $\begin{array}{l}\text { Alexandra Forest } \\
\text { Walk }\end{array}$ & 2008 & $\begin{array}{l}\text { Telok Blangah Hill Park } \\
\text { and Kent Ridge Park of } \\
\text { Southern Ridges, Singapore }\end{array}$ & 1600 & 16 & & & $\sqrt{ }$ & $\sqrt{ }$ & LOOK Architects \\
\hline 12 & $\begin{array}{l}\text { Illawarra Fly } \\
\text { Treetop Walk }\end{array}$ & 2008 & $\begin{array}{c}\text { Knight's Hill, Kiama } \\
\text { Municipality, New South } \\
\text { Wales, Australia }\end{array}$ & 472 & 30 & $\sqrt{ }$ & & & & Canopy 01 \\
\hline 13 & $\begin{array}{l}\text { The Bavarian } \\
\text { Forest Treetop } \\
\text { Walkway }\end{array}$ & 2009 & $\begin{array}{l}\text { Steigerwald Mountainous } \\
\text { Area, Bavarian Forest } \\
\text { National Park, Germany }\end{array}$ & 1300 & 25 & $\sqrt{ }$ & & & & $\begin{array}{c}\text { Die Erlebnis Akademie } \\
\text { AG (eak) }\end{array}$ \\
\hline 14 & $\begin{array}{c}\text { Limb-Tree } \\
\text { Canopy Walkway }\end{array}$ & 2009 & $\begin{array}{l}\text { Morris Arboretum of the } \\
\text { University of Pennsylvania, } \\
\text { USA }\end{array}$ & 140 & 15 & & $\sqrt{ }$ & & & $\begin{array}{l}\text { Metcalfe Architecture } \\
\text { \& Design, PA }\end{array}$ \\
\hline 15 & $\begin{array}{l}\text { Lianhua } \\
\text { Mountainous } \\
\text { Plank Road }\end{array}$ & 2011 & $\begin{array}{c}\text { Lianhua Mountainous } \\
\text { Area, urban district of } \\
\text { Longyan City, Fujian } \\
\text { Province, China }\end{array}$ & 3800 & 15 & & & $\sqrt{ }$ & & $\begin{array}{l}\text { Local urban } \\
\text { construction } \\
\text { department }\end{array}$ \\
\hline 16 & $\begin{array}{l}\text { Westcoast Treetop } \\
\text { Walk }\end{array}$ & 2012 & Christchurch, New Zealand & 450 & 20 & $\sqrt{ }$ & & & & Canopy 01 \\
\hline 17 & $\begin{array}{l}\text { The Lipno Treetop } \\
\text { Walkway }\end{array}$ & 2012 & $\begin{array}{l}\text { Lipno-Stausee Forest, The } \\
\text { Czech Republic }\end{array}$ & 675 & 20 & $\sqrt{ }$ & & & & $\begin{array}{c}\text { Die Erlebnis Akademie } \\
\text { AG (eak) }\end{array}$ \\
\hline 18 & $\begin{array}{l}\text { The Kirstenbosch } \\
\text { Canopy Walkway }\end{array}$ & 2013 & $\begin{array}{l}\text { Kirstenbosch National } \\
\text { Botanical Garden, Cape } \\
\text { Town, South Africa }\end{array}$ & 130 & 12 & & $\sqrt{ }$ & & & $\begin{array}{l}\text { Mark Thomas } \\
\text { Architects }\end{array}$ \\
\hline 19 & $\begin{array}{l}\text { The Naturerbe } \\
\text { Zentrum Rügen } \\
\text { Treetop Walkway }\end{array}$ & 2013 & Rügen Island, Germany & 1250 & 17 & $\sqrt{ }$ & & & & $\begin{array}{c}\text { Die Erlebnis Akademie } \\
\text { AG (eak) }\end{array}$ \\
\hline 20 & $\begin{array}{l}\text { The STIHL } \\
\text { Treetop Walkway }\end{array}$ & 2014 & $\begin{array}{l}\text { Westonbirt National } \\
\text { Arboretum, } \\
\text { Gloucestershire, UK }\end{array}$ & 300 & 13 & & $\sqrt{ }$ & & & $\begin{array}{c}\text { Glenn Howells } \\
\text { Architects (design } \\
\text { work); Buro happold } \\
\text { (engineering work) }\end{array}$ \\
\hline 21 & $\begin{array}{l}\text { 'Baumwipfelpfad } \\
\text { Schwarzwald' The } \\
\text { Black Forest } \\
\text { Treetop Walkway }\end{array}$ & 2014 & $\begin{array}{l}\text { Bad Wildbad, Baden } \\
\text { Württemberg, Germany }\end{array}$ & 1250 & 20 & & $\sqrt{ }$ & & & $\begin{array}{c}\text { Die Erlebnis Akademie } \\
\text { AG (eak) }\end{array}$ \\
\hline 22 & $\begin{array}{l}\text { Rotorua } \\
\text { Redwoods } \\
\text { TreeWalk }\end{array}$ & 2015 & Rotorua, New Zealand & 700 & 20 & $\sqrt{ }$ & & & & Cambium GmbH \\
\hline 23 & $\begin{array}{l}\text { City Viewing } \\
\text { Plank Road of Jinji } \\
\text { Mountain }\end{array}$ & 2015 & $\begin{array}{l}\text { Jinji Mountainous Area, } \\
\text { urban district of Fuzhou, } \\
\text { Fujian Province, China }\end{array}$ & 2680 & 27 & & & $\sqrt{ }$ & $\sqrt{ }$ & $\begin{array}{l}\text { Fujian Rongsheng } \\
\text { Municipal Engineering } \\
\text { Co., Ltd. }\end{array}$ \\
\hline 24 & $\begin{array}{l}\text { Adirondacks Wild } \\
\text { Walk }\end{array}$ & 2015 & $\begin{array}{c}\text { The Wild Center of } \\
\text { Adirondacks, New York } \\
\text { State, USA }\end{array}$ & 390 & 15 & & $\sqrt{ }$ & & & $\begin{array}{l}\text { Adirondacks Park } \\
\text { Agency }\end{array}$ \\
\hline 25 & $\begin{array}{c}\text { The Fu Forest } \\
\text { Trail }\end{array}$ & 2016 & $\begin{array}{l}\text { Jinniu Mountainous Area, } \\
\text { urban district of Fuzhou, } \\
\text { Fujian Province, China }\end{array}$ & 6200 & 15 & & & $\sqrt{ }$ & $\sqrt{ }$ & $\begin{array}{l}\text { LOOK Architects and } \\
\text { Arup Singapore Pte. } \\
\text { Ltd. }\end{array}$ \\
\hline 26 & $\begin{array}{l}\text { The Saarschleife } \\
\text { Treetop Walkway }\end{array}$ & 2016 & $\begin{array}{l}\text { Saar-Hunsrück Natural } \\
\text { Park, Saarschleife Area, } \\
\text { Saarland, Germany }\end{array}$ & 1250 & 23 & $\sqrt{ }$ & & & & $\begin{array}{c}\text { Die Erlebnis Akademie } \\
\text { AG (eak) }\end{array}$ \\
\hline 27 & $\begin{array}{l}\text { Plank Road of } \\
\text { Huagai Hill }\end{array}$ & 2016 & $\begin{array}{c}\text { Mountainous area in urban } \\
\text { district, Foshan City, } \\
\text { Guangdong Province, } \\
\text { China }\end{array}$ & 1600 & 20 & & & $\sqrt{ }$ & & $\begin{array}{l}\text { Local urban } \\
\text { construction } \\
\text { department }\end{array}$ \\
\hline 28 & $\begin{array}{l}\text { Daping } \\
\text { Mountainous } \\
\text { Greenway }\end{array}$ & 2017 & $\begin{array}{l}\text { Daping Mountainous Area, } \\
\text { urban district of Quanzhou, } \\
\text { Fujian Province, China }\end{array}$ & 4040 & 20 & & & $\sqrt{ }$ & $\sqrt{ }$ & $\begin{array}{l}\text { Local urban } \\
\text { construction } \\
\text { department }\end{array}$ \\
\hline 29 & $\begin{array}{l}\text { The Krkonoše } \\
\text { National Park } \\
\text { Tree Top Walkway }\end{array}$ & 2017 & $\begin{array}{l}\text { Krkonoše National Park, } \\
\text { The Czech Republic }\end{array}$ & 1511 & 24 & $\sqrt{ }$ & & & & $\begin{array}{c}\text { Die Erlebnis Akademie } \\
\text { AG (eak) }\end{array}$ \\
\hline 30 & $\begin{array}{l}\text { The Bachledka } \\
\text { Treetop Walkway }\end{array}$ & 2017 & $\begin{array}{l}\text { The Bachledova Valley, The } \\
\text { Slovak Republic }\end{array}$ & 1234 & 24 & $\sqrt{ }$ & & & & $\begin{array}{c}\text { Die Erlebnis Akademie } \\
\text { AG (eak) }\end{array}$ \\
\hline 31 & $\begin{array}{l}\text { Forest Science } \\
\text { Popularization } \\
\text { Plank Road }\end{array}$ & 2017 & $\begin{array}{l}\text { Huanglong County, Yan'an, } \\
\text { Shanxi Province, China }\end{array}$ & 1390 & 24 & $\sqrt{ }$ & $\sqrt{ }$ & & & $\begin{array}{l}\text { Local urban } \\
\text { construction } \\
\text { department }\end{array}$ \\
\hline 32 & Qingjing Skywalk & 2017 & $\begin{array}{l}\text { Qingjing Farm, Nantou, } \\
\text { Taiwan, China }\end{array}$ & 1200 & 15 & & $\sqrt{ }$ & & & Heinrich Roth GmbH \\
\hline
\end{tabular}


Table A1. Cont.

\begin{tabular}{|c|c|c|c|c|c|c|c|c|c|c|}
\hline \multirow[b]{2}{*}{ No. } & \multirow{2}{*}{ Name } & \multirow[b]{2}{*}{ OT * } & \multirow{2}{*}{ Location } & \multirow{2}{*}{$E L *(m)$} & \multirow{2}{*}{$\mathrm{MSH}^{*}(\mathrm{~m})$} & \multicolumn{4}{|c|}{ Main Uses } & \multirow{2}{*}{$\begin{array}{c}\text { Designers/ } \\
\text { Contractors/Owners }\end{array}$} \\
\hline & & & & & & CFTP * & FRF * & UPL * & UMG * & \\
\hline 33 & $\begin{array}{l}\text { The } \\
\text { Salzkammergut } \\
\text { Treetop Walkway }\end{array}$ & 2018 & $\begin{array}{c}\text { Grünberg, Salzkammergut, } \\
\text { Austria }\end{array}$ & 1400 & 21 & $\sqrt{ }$ & & & & $\begin{array}{c}\text { Akademie AG in } \\
\text { Austria }\end{array}$ \\
\hline 34 & $\begin{array}{l}\text { Mount Archer } \\
\text { Treetop } \\
\text { Broadwalk }\end{array}$ & 2018 & $\begin{array}{l}\text { Frazer Park, Rockhampton, } \\
\text { Queensland, Australia }\end{array}$ & 500 & 12 & & $\sqrt{ }$ & & & $\begin{array}{l}\text { Rockhampton } \\
\text { Regional Council }\end{array}$ \\
\hline 35 & $\begin{array}{l}\text { Neckertal Treetop } \\
\text { Walkway }\end{array}$ & 2018 & $\begin{array}{c}\text { Town of St. Gallen, } \\
\text { Mogelsberg, Switzerland }\end{array}$ & 500 & 16 & & $\sqrt{ }$ & & & \\
\hline 36 & $\begin{array}{l}\text { The Serralves } \\
\text { Canopy Walkway }\end{array}$ & 2019 & $\begin{array}{c}\text { Serralves Park, Porto, } \\
\text { Portugal }\end{array}$ & 260 & 25 & & $\sqrt{ }$ & & & $\begin{array}{l}\text { Carlos Castanheira, } \\
\text { CC\&CB Architects }\end{array}$ \\
\hline 37 & $\begin{array}{c}\text { Xiamen } \\
\text { Mountains-to-Sea } \\
\text { Trail }\end{array}$ & 2020 & $\begin{array}{l}\text { Urban district of Xiamen, } \\
\text { Fujian Province, China }\end{array}$ & 10,200 & 25 & & & $\sqrt{ }$ & $\sqrt{ }$ & $\begin{array}{l}\text { Xiamen Municipal } \\
\text { Development } \\
\text { Company }\end{array}$ \\
\hline 38 & $\begin{array}{l}\text { The Pohorje } \\
\text { Treetop Walkway }\end{array}$ & 2021 & $\begin{array}{l}\text { Atop Rogla Mountain, the } \\
\text { heart of the forests of the } \\
\text { Pohorje, Republic of } \\
\text { Slovenia }\end{array}$ & 1043 & 20 & $\sqrt{ }$ & & & & $\begin{array}{c}\text { Die Erlebnis Akademie } \\
\text { AG (eak) }\end{array}$ \\
\hline 39 & $\begin{array}{l}\text { The Alsace } \\
\text { Treetop Walk }\end{array}$ & 2021 & $\begin{array}{l}\text { Northern Vosges Nature } \\
\text { Park, Drachenbronn Town, } \\
\text { France }\end{array}$ & 1050 & 29 & $\sqrt{ }$ & & & & $\begin{array}{c}\text { Die Erlebnis Akademie } \\
\text { AG (eak) }\end{array}$ \\
\hline 40 & $\begin{array}{l}\text { The Usedom } \\
\text { Treetop Walk }\end{array}$ & 2021 & $\begin{array}{l}\text { The Island of Usedom, } \\
\text { Germany }\end{array}$ & 1350 & 23 & $\sqrt{ }$ & & & & $\begin{array}{c}\text { Die Erlebnis Akademie } \\
\text { AG (eak) }\end{array}$ \\
\hline
\end{tabular}

* OT: open time; year opened to the public; EL: elevated length; the length of the elevated segment; MSH: the maximum suspended height; CFTP: commercial forest tourism projects; FRF: forest recreational facilities; UPL: urban public landscape; UMG: urban mountainous greenway. This refers to projects included in urban greenway plans; WATC: Western Australian Tourism Commission. DALM: Department of Conservation and Land Management.

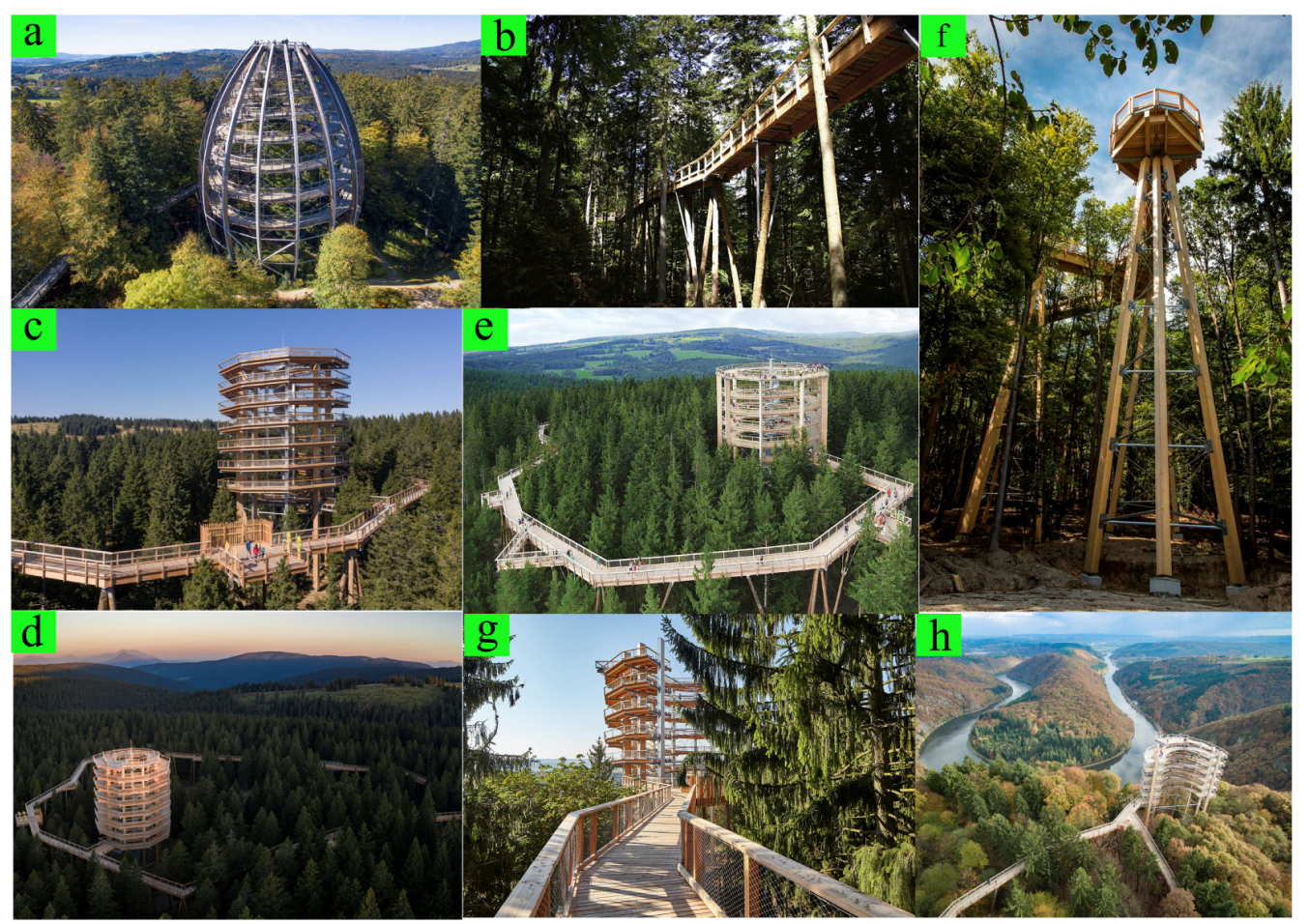

Figure A1. The treetop walkways in European countries built by die Erlebnis Akademie Ag (eak) of Germany (Source: https:/ / www.baumwipfelpfade.de/nezr/nezr/, accessed on 25 July 2021). (a,b) The Bavarian Forest Treetop Walkway, Bavarian Forest National Park, Germany. (c,e) The Lipno Treetop Walkway, Lipno-Stausee Forest, The Czech Republic. (d,f) The Pohorje Treetop Walkway, the forests of the Pohorje, Republic of Slovenia. $(\mathbf{g}, \mathbf{h})$ The Saarschleife Treetop Walkway, Saar-Hunsrück Natural Park, Germany. 


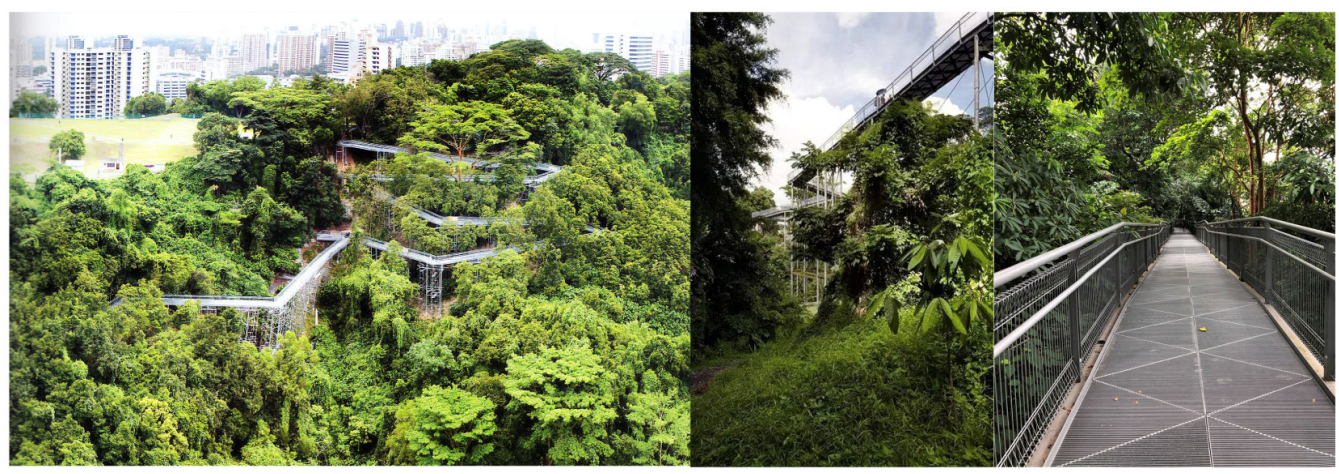

Figure A2. The treetop walkway of the Southern Ridges Greenway in Singapore (Source: https: / /en.wikipedia.org/wiki/Southern_Ridges, accessed on 15 July 2021; and reference [56]).

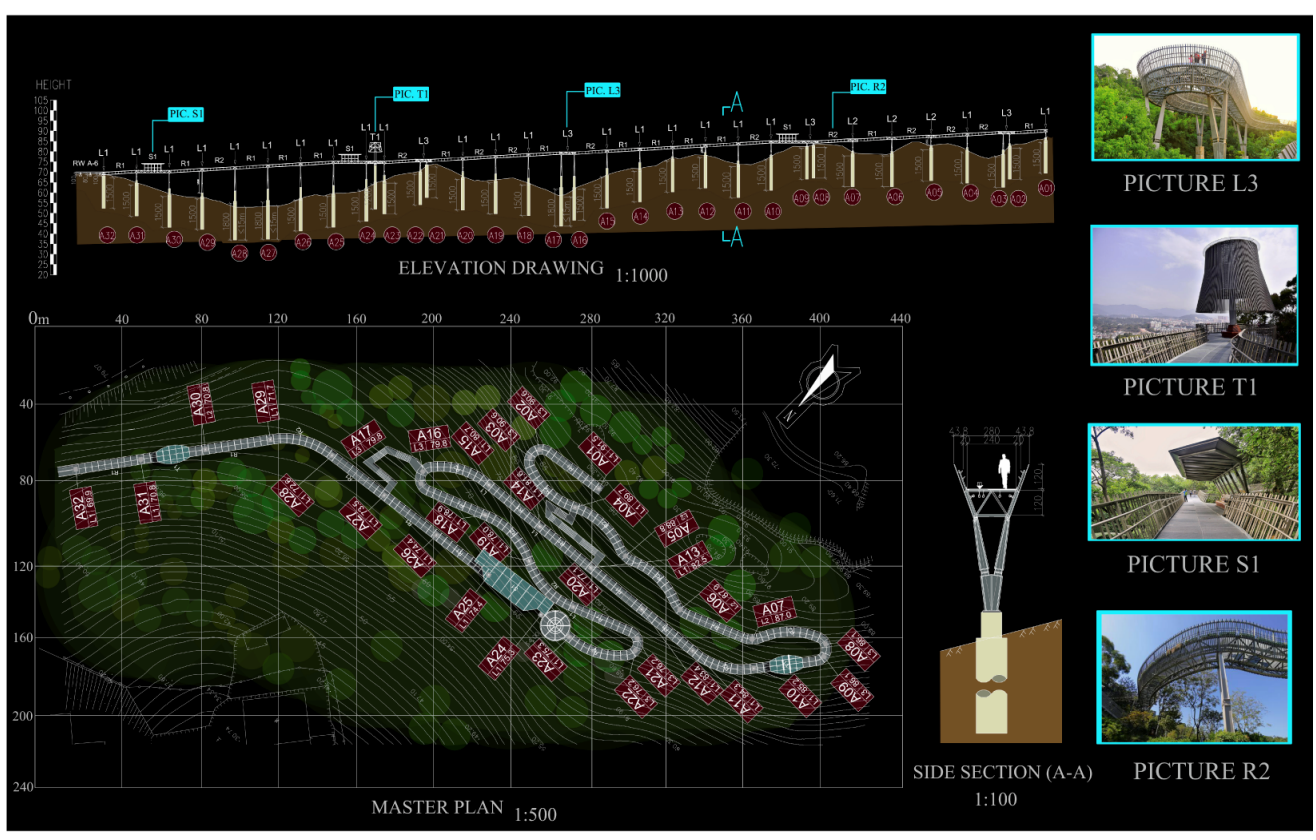

Figure A3. The combination of different modules for one section of the Fu Forest Trail (Source: author's work). 


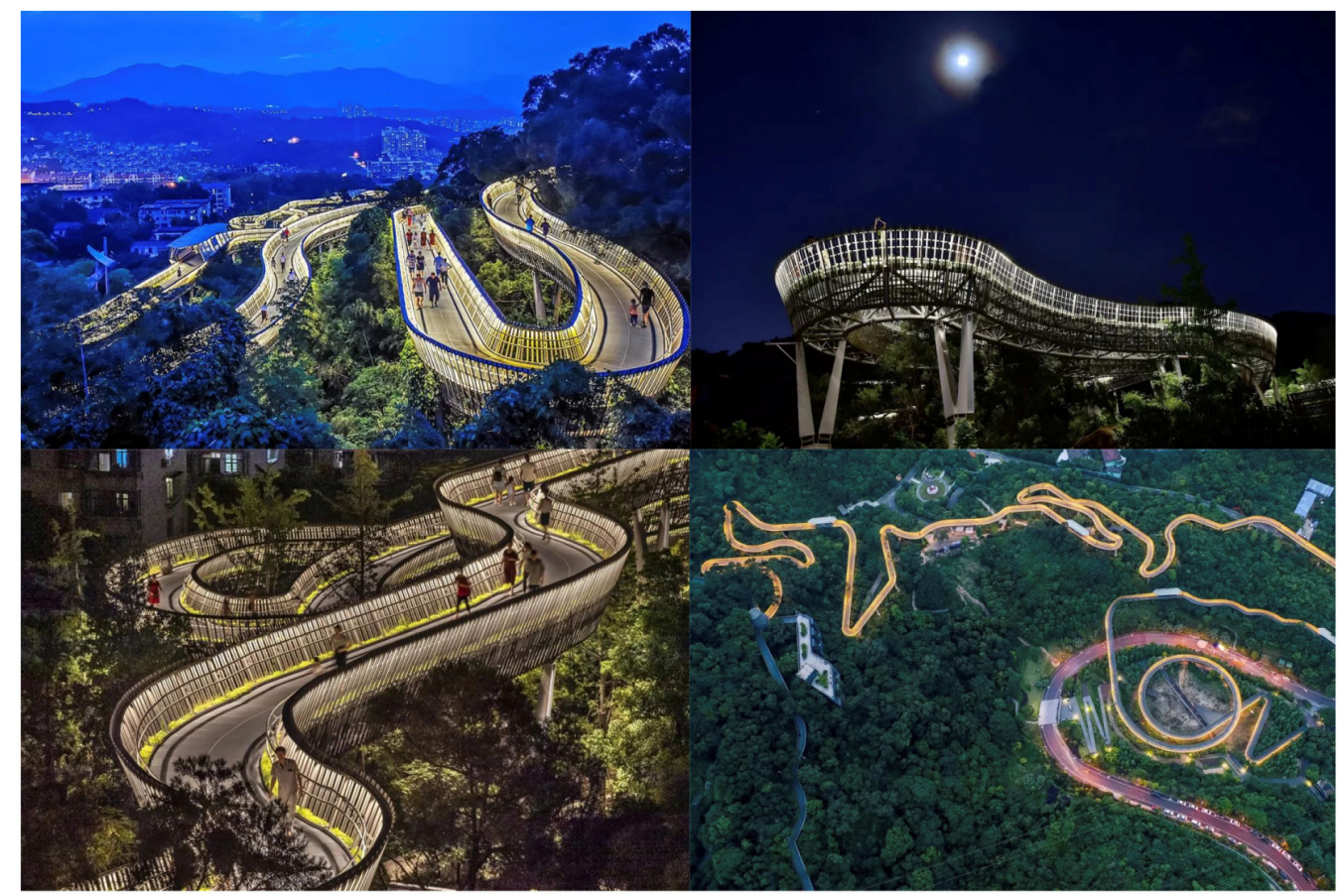

Figure A4. The LED lighting system of the Fu Forest trail (Source: https:/ /www.sohu.com/a/3285 64388_99964897, accessed on 31 July 2021).
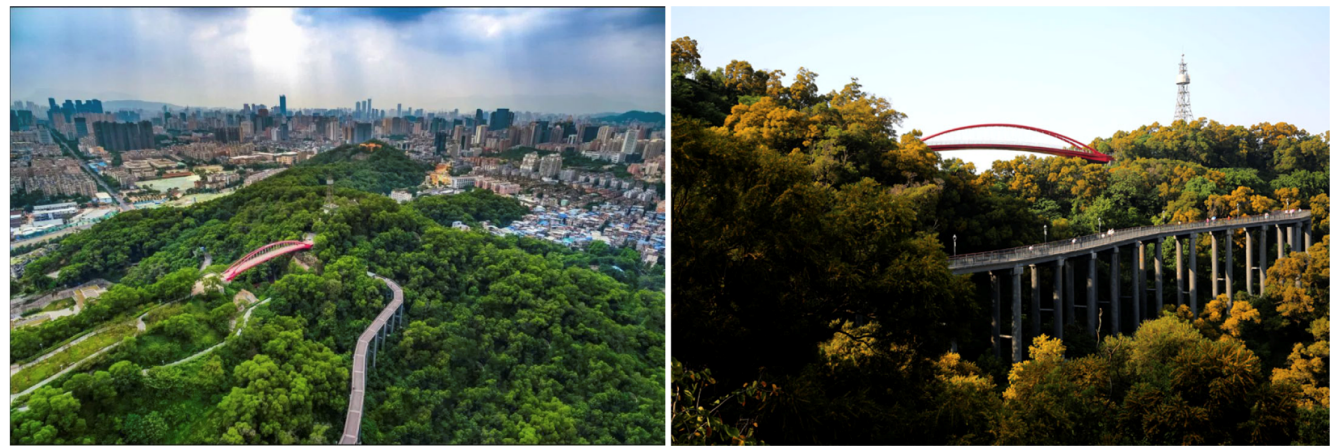

Figure A5. The pictures of "City Viewing Plank Road" of Jinji Mountainous Park in Fuzhou. 


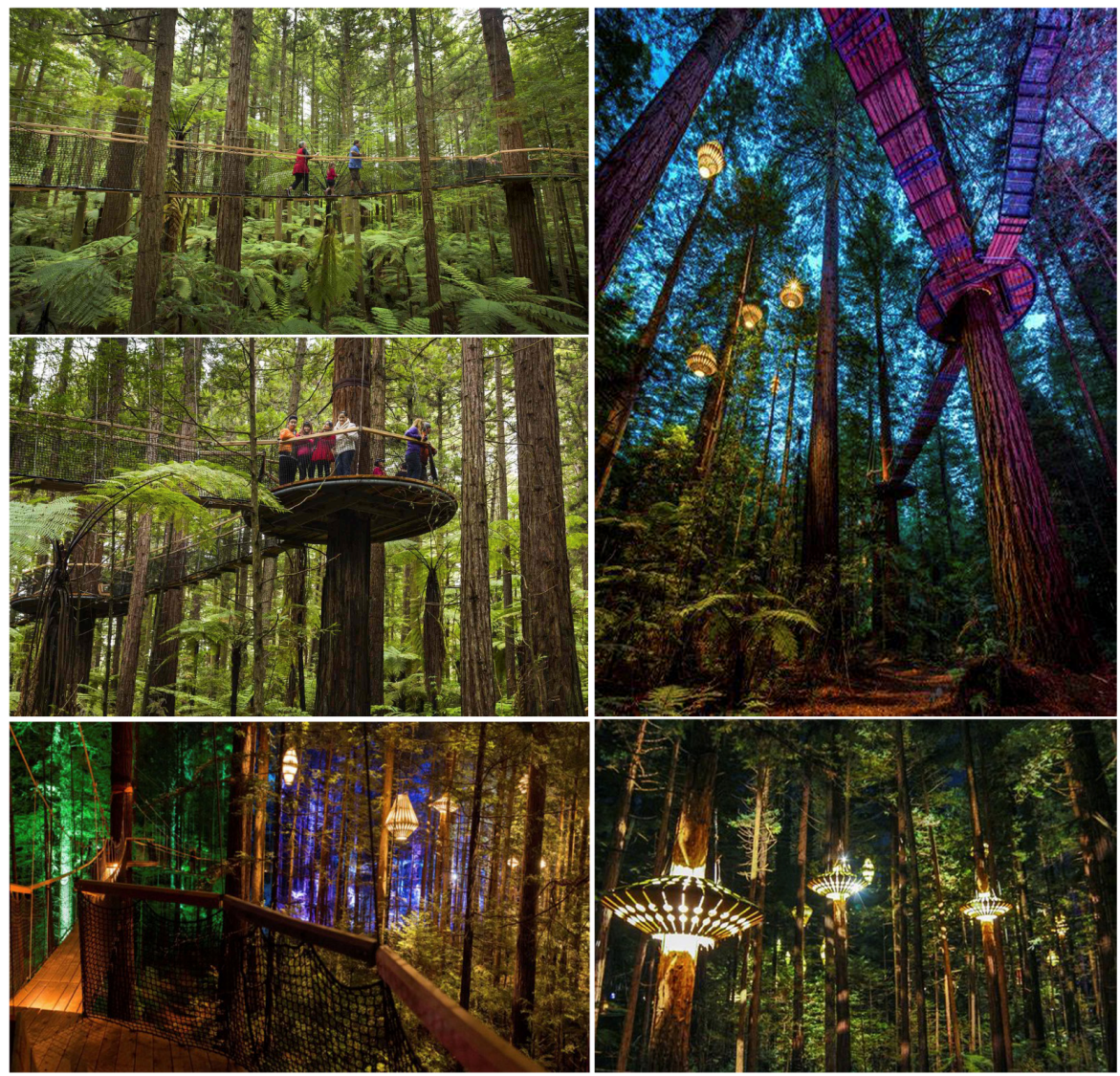

Figure A6. Photos of the Rotorua Redwoods Treewalk in New Zealand (Source: https:/ /www. newzealand.com/uk/plan/business/redwoods-treewalk/, accessed on 15 July 2021).

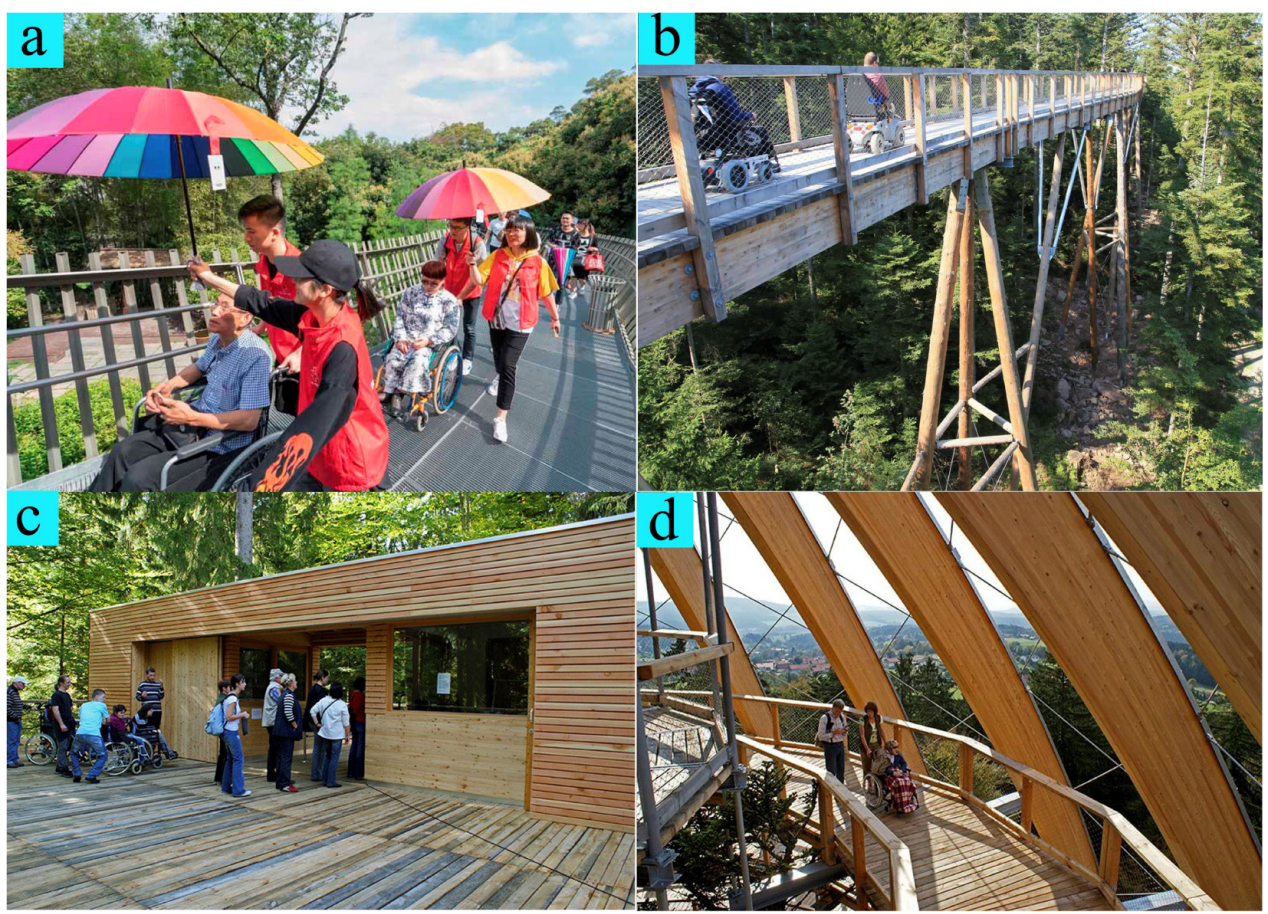

Figure A7. Treetop walkways with gentle slope changes are friendly to disadvantaged groups. The disabled in wheelchairs in (a) the Fu Forest Trail, (b) the Lipno Treetop Walkway, the Czech Republic, and $(\mathbf{c}, \mathbf{d})$ in the Bavarian Forest Treetop Walkway, Germany. 


\section{References}

1. Zhang, T.; Zhang, W.K.; Meng, H.; Zhang, Z. Analyzing Visitors' Preferences and Evaluation of Satisfaction Based on Different Attributes, With Forest Trails in the Akasawa National Recreational Forest, Central Japan. Forests 2019, 10, 431. [CrossRef]

2. Wilkes-Allemann, J.; Hanewinkel, M.; Pütz, M. Forest Recreation as a Governance Problem: Four Case Studies From Switzerland. Eur. J. For. Res. 2017, 136, 511-526. [CrossRef]

3. Hunziker, M.; Kienast, F. Potential Impacts of Changing Agricultural Activities on Scenic Beauty: A Prototypical Technique for Automated Rapid Assessment. Landsc. Ecol. 1999, 14, 161-176. [CrossRef]

4. Tahvanainen, L.; Tyrväinen, L.; Ihalainen, M.; Vuorela, N.; Kolehmainen, O. Forest Management and Public Perceptions-Visual Versus Verbal Information. Landsc. Urban Plan. 2001, 53, 53-70. [CrossRef]

5. Deng, S.Q.; Yin, N.; Guan, Q.W.; Katoh, M. Short-Term Effects of Thinning Intensity on Scenic Beauty Values of Different Stands. J. For. Res. 2013, 18, 209-219. [CrossRef]

6. Gong, L.; Zhang, Z.D.; Xu, C.Y. Developing a Quality Assessment Index System for Scenic Forest Management: A Case Study from Xishan Mountain, Suburban Beijing. Forests 2015, 6, 225-243. [CrossRef]

7. Hörnsten, L.; Fredman, P. On the Distance to Recreational Forests in Sweden. Landsc. Urban Plan. 2000, 51, 1-10. [CrossRef]

8. Burgin, S.; Hardiman, N. Extreme Sports in Natural Areas: Looming Disaster or a Catalyst for a Paradigm Shift in Land Use Planning? J. Environ. Plan. Manag. 2012, 55, 921-940. [CrossRef]

9. Oku, H.; Fukamachi, K. The Differences in Scenic Perception of Forest Visitors Through Their Attributes and Recreational Activity. Landsc. Urban Plan. 2006, 75, 34-42. [CrossRef]

10. Hartig, T.; Evans, G.W.; Jamner, L.D.; Davis, D.S.; Gärling, T. Tracking Restoration in Natural and Urban Field Settings. J. Environ. Psychol. 2003, 23, 109-123. [CrossRef]

11. Faryadi, S.; Taheri, S. Interconnections of Urban Green Spaces and Environmental Quality of Tehran. Int. J. Environ. Resour. 2009, 3, 199-208. Available online: http:/ / hdl.handle.net/1807/49435 (accessed on 31 July 2021).

12. Zhou, C.W.; Yan, L.B.; Yu, L.F.; Wei, H.X.; Guan, H.M.; Shang, C.F.; Chen, F.Y.; Bao, J. Effect of Short-Term Forest Bathing in Urban Parks on Perceived Anxiety of Young-Adults: A Pilot Study in Guiyang, Southwest China. Chin. Geogr. Sci. 2019, 29, 139-150. [CrossRef]

13. Guan, H.; Wei, H.X.; He, X.Y.; Ren, Z.B.; An, B.Y. The Tree-Species-Specific Effect of Forest Bathing on Perceived Anxiety Alleviation of Young-Adults in Urban Forests. Ann. For. Res. 2017, 60, 327-341. [CrossRef]

14. Ulrich, R.S. Effects of Natural View and Urban View on Human Emotion and Physiology. Environ. Behav. 1981, 13, 523-556. [CrossRef]

15. Ulrich, R.S. View Through a Window May Influence Recovery from Surgery. Science 1984, 224, 420-421. [CrossRef]

16. Zeng, Z.; Zhu, N.Y.; Wang, D.; Cheng, H.S.; Fan, X.L.; Huang, P.; Lan, S.R.; Li, X.H. Research on Urban Greenways Optimization Strategy Based on the Tourist Recreational Motivation and Behavior Characteristics: A Case in Fu Forest Trail of Fuzhou City. J. Shandong Agric. Univ. Nat. Sci. Ed. 2018, 49, 639-645. (In Chinese) [CrossRef]

17. Huang, Y.B.; Fu, W.C.; Wen, Y.X.; Wang, M.H. A Study on the Relationship Between Individual Landscape Preference, Perceived Restorativeness Scale and Health Benefits Assessment of Urban Forest Pathway: A Case Study of Fudao. Chin. Landsc. Archit. 2020, 36, 73-78. (In Chinese) [CrossRef]

18. Wang, Z.N.; Luo, P.C.; Zhan, H.Z.; Zhao, X.X.; Tang, Y.X.; Liu, H.L. Research on the Influence of Urban Leisure Green Road Recreational Involvement on Well-Being: Taking Fu Forest Trail of Fuzhou as an Example. J. Fujian Norm. Univ. (Nat. Sci. Ed.) 2020, 36, 70-78. Available online: https://kns.cnki.net/kcms/detail / detail.aspx?FileName=FJSZ202003009\&DbName=CJFQ2020 (accessed on 5 June 2021). (In Chinese).

19. Cao, L.W.; Qie, G.F.; Jiang, S.S. Analysis of Development and Functional Characteristics of Aerial Forest Trail. World For. Res. 2019, 32, 48-52. (In Chinese) [CrossRef]

20. LOOK Architects (Singapore). Jin Niu Shan Trans-Urban Connector (Fudao), Fuzhou, China. World Archit. 2018, 9, 94-101. [CrossRef]

21. Pan, R.C. New Concept of Urban Forest Trail Design: The Fuzhou Fudao Project Is Selected as the Example. J. Fujian For. Sci. Technol. 2020, 47, 82-86. (In Chinese) [CrossRef]

22. LOOK Architects; Arup, Singapore. Design of the Fudao Forest Walkway in Fuzhou. Landsc. Archit. Front. 2018, 6, 67-73. (In Chinese) [CrossRef]

23. Schwarzer, M. The Tree Canopy as Blueprint. Archit. Des. 2010, 80, 20-27. [CrossRef]

24. Lowman, M.D.; Burgess, E.; Burgess, J. It's a Jungle up There: More Tales from the Treetops; Yale University Press: New Haven, CT, USA, 2006; pp. 12-14. Available online: https:/ / www.jstor.org/stable/j.ctt1njkvs (accessed on 5 July 2021).

25. Nadkarni, N.M. Diversity of Species and Interactions in the Upper Tree Canopy of Forest Ecosystems. Am. Zool. 1994, 34, 70-78. [CrossRef]

26. Mitchell, A.; Secoy, K.; Jackson, T. The Global Canopy Handbook: Techniques of Access and Study in the Forest Roof; Global Canopy Programme: Oxford, UK, 2002; pp. 35-209.

27. Halle, F. Canopy Architecture in Tropical Trees: A Pictorial Approach. In Forest Canopies; Nadkarni, N., Lowman, M., Eds.; Academic Press: San Diego, CA, USA, 1995; pp. 6-32. Available online: https://www.researchgate.net/publication/281981169_ Canopy_architecture_in_tropical_trees_A_pictorial_approach (accessed on 5 July 2021). 
28. Hughes, M.; Morrison-Saunders, A. Repeat and First Time Visitation in an Experience Specific Context: The Valley of the Giants Tree Top Walk. J. Tour. Stud. 2002, 13, 20-25. Available online: https://search.informit.org/doi/10.3316/IELAPA.200208352 (accessed on 5 July 2021).

29. Morin, S.L.; Moore, S.A.; Schmidt, W. Defining Indicators and Standards for Recreation Impacts in Nuyts Wilderness, WalpoleNornalup National Park, Western Australia. CALMScience 1997, 2, 247-266. Available online: https:/ / www.researchgate.net/ publication/44150539 (accessed on 5 July 2021).

30. Smith, A.J.; Newsome, D. An Investigation into the Concept of and Factors Leading to Impact Creep and Its Management; The Cooperative Research Centre (CRC) for Sustainable Tourism Pty Ltd.: Gold Coast, Australia, 2006; pp. 40-50. Available online: https:/ / www.researchgate.net/publication/46168005 (accessed on 5 July 2021).

31. Western Australian Department of Conservation and Land Management. Walpole-Nornalup National Park Management Plan 1992-2002; Department of Western Australian Department of Conservation and Land Management: Perth, Australia, 1992.

32. Western Australian Department of Conservation and Land Management. Tree Top Walk E Valley of the Giants Redevelopment, Report for Corporate Executive, Valley of the Giants Project Team; Department of Western Australian Department of Conservation and Land Management: Perth, Australia, 1994.

33. Western Australian Department of Conservation and Land Management. Walpole-Nornalup National Park Visitor Feedback Program, Feb. to Apr. 2000; Department of Western Australian Department of Conservation and Land Management: Perth, Australia, 2000.

34. Western Australian Department of Conservation and Land Management. Walpole-Nornalup National Park Visitor Feedback Program, Dec. 2000 to Apr. 2001; Department of Western Australian Department of Conservation and Land Management: Perth, Australia, 2001.

35. Western Australian Department of Conservation and Land Management. Tree Top Walk Comment Card Summary in 2003; CALM VISTAT System; Department of Western Australian Department of Conservation and Land Management: Nornalup, Australia, 2003.

36. Western Australian Department of Conservation and Land Management. Tree Top Walk Source Visitation Analysis in 2002/3; Department of Western Australian Department of Conservation and Land Management: Nornalup, Australia, 2003.

37. Western Australian Department of Conservation and Land Management. Tree Top Walk Comment Card Summary in 2004; Department of Western Australian Department of Conservation and Land Management: Nornalup, Australia, 2004.

38. Goff, R. The Economic Value of Tourism and Recreation in Forested Areas of the Economic Value of Tourism and Recreation in Forested Areas of Western Australia. Master's Thesis, Edith Cowan University, Perth, Australia, 2003. Available online: https:/ / ro.ecu.edu.au/theses/1302 (accessed on 5 July 2021).

39. Freedman, G. Salcey Treetop Walk. Eng. Sustain. 2009, 162, 215-222. [CrossRef]

40. Ztürk, M.; Gülgün, B. Chapter 5 Hardscape Elements in Landscape Architecture-A Case Study: Treetop Walkway in Bavarian Forest National Park, Germany. In Research \& Reviews in Architecture, Planning and Design; Gece Kitapliğ1: Ankara, Turkey, 2021; Volumes 89-92, Available online: https:/ / www.researchgate.net/publication/349678307 (accessed on 1 August 2021).

41. Chen, S. A Breathing Bridge: Kew Treetop Walkway in Royal Botanic Garden of London. Interior Des. Constr. 2010, 3, 90-93. (In Chinese) [CrossRef]

42. Demir, A. The Visitor Profile and Conservation Value of Royal Botanic Garden, KEW. Energy Educ. Sci. Technol. B 2012, 1037-1043. Available online: https:/ / www.researchgate.net/publication/259285227 (accessed on 31 July 2021).

43. Homepage of Royal Botanic Garden, Kew, London, UK. Available online: https:/ /www.kew.org/kew-gardens/whats-in-thegardens / treetop-walkway (accessed on 25 July 2021).

44. Madden, J.; Groenewold, N.; Thapa, P. Estimating the Value of Tasmanian National Parks to Park Visitors, The Sustainable Tourism Cooperative Research Centre. 2002. Available online: http:/ / ecite.utas.edu.au/22899 (accessed on 5 July 2021).

45. West Coast Tree Top Walk, Christchurch, New Zealand. Available online: https://www.newzealand.com/ie/plan/business/ west-coast-tree-top-walk/ (accessed on 25 July 2021).

46. The Bavarian Forest Tree Top Walkway, Steigerwald Mountainous Area, Bavarian Forest National Park, Germany. Available online: https: / / www.baumwipfelpfade.de/en/bayerischer-wald/ (accessed on 25 July 2021).

47. The Lipno Treetop Walkway, Lipno-Stausee Forest, The Czech Republic. Available online: https://www.stezkakorunamistromu. cz/en/about-trail (accessed on 25 July 2021).

48. The Naturerbe Zentrum Rügen Treetop Walkway, Rügen Island, Germany. Available online: https://www.baumwipfelpfade.de/ en/nezr/ (accessed on 25 July 2021).

49. The Black Forest Treetop Walkway, Bad Wildbad, Baden Württemberg, Germany. Available online: https://www. baumwipfelpfade.de/en/schwarzwald/ (accessed on 25 July 2021).

50. The Saarschleife Treetop Walkway, Saarland, Germany. Available online: https://www.baumwipfelpfade.de/en/saarschleife/ index.php (accessed on 25 July 2021).

51. The Krkonoše National Park Tree Top Walkway, Krkonoše National Park, The Czech Republic. Available online: https://www. stezkakrkonose.cz/en/about-trail (accessed on 25 July 2021).

52. The Bachledka Treetop Walkway, the Bachledova Valley, The Republic of Slovenia. Available online: https://chodnikkorunamistromov. sk/en/about-the-trail/ (accessed on 25 July 2021).

53. The Pohorje Tree Top Walkway, the Forests of Pohorje, The Republic of Slovenia. Available online: https://www. potmedkrosnjamipohorje.si/en/about-trail (accessed on 25 July 2021). 
54. The Alsace Tree Top Walk, the Northern Vosges Nature Park, Drachenbronn Town, France. Available online: https://www. baumwipfelpfade.de/en/alsace/ (accessed on 25 July 2021).

55. The Usedom Tree Top Walk, the Island of Usedom, Germany. Available online: https://www.baumwipfelpfade.de/en/usedom/ (accessed on 25 July 2021).

56. Li, P. Alexandra Arch and Forest Walk, Singapore. World Archit. 2009, 9, 70-73. [CrossRef]

57. Liu, Y.B. Research of Planning and Design Methods of Urban Hilly Greenway. Master's Thesis, Huazhong University of Science \& Technology, Wuhan, China, 2018; pp. 34-35. Available online: https://kns.cnki.net/KCMS/detail/detail.aspx?dbname=CMFD2 01901\&filename $=1018781881$.nh (accessed on 31 July 2021). (In Chinese).

58. Southern Ridges, Singapore. Available online: https:/ / en.wikipedia.org/wiki/Southern_Ridges (accessed on 15 July 2021).

59. Lin, Y.B.; Ke, Y.; Konijnendijk, C.C.; Yu, K.Y.; Zhong, Y.; Liu, J. Bird Eye Analysis of Skyline Views from an Elevated Recreation Trail: The Case of the Fu Forest Trail, Fuzhou, China. Urban For. Urban Gree. 2020, 47, 126543. [CrossRef]

60. Lin, Y.B.; Liu, J.; Yu, K.Y.; Ke, Y. Research on Perceived Evaluation for Landscape Environment of Treetop Walk: A Case Study of "Fu Forest Trail" in Fuzhou, China. Landsc. Archit. 2019, 35, 72-77. (In Chinese) [CrossRef]

61. Xiao, Z.R. The Conceptual Design and Structural Analyses of Feihong Bridge at the Jinjishan Park in Fuzhou. Fujian Archit. Constr. 2017, 6, 107-109. Available online: http:/ / www.cnki.com.cn/article/cjfdtotal-fjjz201706026.htm (accessed on 15 July 2021). (In Chinese).

62. Wu, M.T. Design of Mountain Park Trails: With Case Study on Fuzhou Jinjishan Park. Fujian Archit. Constr. 2013, 7, 49-51. Available online: http:/ / www.cnki.com.cn/Article/CJFDTotal-FJJZ201307017.htm (accessed on 20 July 2021). (In Chinese).

63. Wang, W.K. Practice and Study on the Constructions of Greenway System in Shan-Shui City of Fuzhou. Fujian Constr. Sci. Technol. 2017, 2, 39-43. (In Chinese) [CrossRef]

64. Xu, X.L.; Zhu, Z.P.; Chen, Z.R.; Zheng, X.; Dong, J.W. Comprehensive Evaluation of Urban Forest Trail: Taking Fudao as an Example. J. Northwest. Norm. Univ. Nat. Sci. 2018, 54, 109-115. (In Chinese) [CrossRef]

65. Sun, F.M. Out on a Limb-Tree Canopy Walk Centerpiece of Tree Adventure Exhibit at Morris Arboretum of the University of Pennsylvania. Landsc. Archit. 2011, 2011, 114-121. [CrossRef]

66. Redwoods Treewalk, Rotorua, New Zealand. Available online: https://www.newzealand.com/uk/plan/business/redwoodstreewalk/ (accessed on 15 July 2021).

67. Zhang, X.; Chen, J.X.; Lin, Q.X.; Yao, Y.Q.; Liu, J. Research on Soundscape Evaluation of Urban. Leisure Trail Based on Grounded Theory: Take Fuzhou Fu Road as an Example. Archit. Cult. 2019, 11, 88-90. Available online: https://kns.cnki.net/kcms/detail/ detail.aspx?FileName=JZYW201911030\&DbName=CJFQ2019 (accessed on 15 July 2021). (In Chinese).

68. Wang, Y.L. Research on Trail Planning of Fuzhou Jinji Mountain Park Based on the Concept of Forest Climatotherapy. Master's Thesis, Fujian Agriculture and Forestry University, Fujian, China, 2016; pp. 46-59. Available online: https://kns.cnki.net/KCMS/ detail/detail.aspx?dbname=CMFD201602\&filename=1016134371.nh (accessed on 15 July 2021). (In Chinese).

69. Gao, Y.C.; Yu, K.Y.; Liu, Y.F.; Yang, L.Q.; Chen, F.F.; Liu, J. Autumn Microclimate Effect of Canopy Trail: A Case Study of Fu Forest Trail in Fuzhou. J. Northwest. For. Univ. 2021, 36, 266-272. [CrossRef]

70. Aziz, R.C. Development of Sustainable Rural Tourism at Sungai Sedim Amenity Forest, Kedah, Malaysia from a Tourism Stakeholders' Perspective. Ph.D. Thesis, Universiti Putra Malaysia, Serdang, Malaysia, 2016; pp. 8-11. Available online: http:/ / psasir.upm.edu.my/id/eprint/ 69323 (accessed on 15 July 2021).

71. Mitchell, W.J.T. Landscaped and Power, 2nd ed.; University of Chicago Press: Chicago, IL, USA, 2002; Available online: https: //www.press.uchicago.edu/ucp/books/book/chicago/L/bo3626791.html (accessed on 15 July 2021).

72. Wang, W.K. The Ideality, Action, Difficulty and Countermeasure of the Mountain Protection in the City: The Practice and Study on the Mountain Protection in Fuzhou. Fujian Archit. Constr. 2017, 3, 11-15. Available online: https://kns.cnki.net/kcms/detail/ detail.aspx?FileName=FJJZ201703003\&DbName=CJFQ2017 (accessed on 10 July 2021). (In Chinese).

73. Guo, M. Assessing the Suitability of Urban Greenway Resources and Spatial Structure: A Case Study in Fuzhou City. Master's Thesis, Fujian Agriculture and Forestry University, Fujian, China, 2015; pp. 46-59. Available online: https://kns.cnki.net/KCMS / detail / detail.aspx?dbname=CMFD201602\&filename=1015376145.nh (accessed on 15 July 2021). (In Chinese).

74. Darcy, J. The STIHL Treetop Walkway: Westonbirt Arboretum. IABSE Symp. Rep. 2017, 108, 62-63. [CrossRef]

75. STIHL Treetop Walkway, Westonbirt National Arboretum, Gloucestershire, UK. Available online: https://www.forestryengland. uk/westonbirt/stihl-tree-top-walkway (accessed on 31 July 2021).

76. Adirondacks Wild Walk, The Wild Center of Adirondacks, New York State, USA. Available online: https://www.wildcenter.org/ visit/wild-walk/ (accessed on 31 July 2021).

77. Ba, C. Research on the Design and Application of Small Steel Bridge in Urban Parks. Master's Thesis, Beijing Forestry University, Beijing, China, 2015; pp. 82-84. Available online: https://kns.cnki.net/KCMS/detail/detail.aspx?dbname=CMFD201502\& filename=1015319747.nh (accessed on 5 July 2021). (In Chinese). 